\title{
CÉLESTIN E ÉLISE FREINET: UNHA PEDAGOXÍA DO SÉCULO XX QUE SE RENOVA NO PRESENTE ${ }^{1}$
}

\section{CÉLESTIN AND ÉLISE FREINET: A 20TH CENTURY PEDAGOGY THAT IS RENOVATED IN THE PRESENT}

\author{
http://dx.doi.org/10.15304/ie.29.6284 \\ Antón Costa Rico \\ de Nova Escola Galega / Universidade de Santiago de Compostela \\ anton.costa@usc.es
}

\section{RESUMO}

Célestin Freinet, cunha inquedanza intelectual, emocional e social extraordinaria, levou adiante unha intensa acción pedagóxica entre 1920 e 1966. Fíxoo con capacidade renovadora das escolas ao propoñer novas técnicas, instrumentos e recursos didácticos e novas orientacións de filosofía educativa, a partir dunha intensa experimentación práctica, constantemente reflexionada e teorizada, fusionando niso aspectos da corrente escolar socialista, do pragmatismo deweyano, do activismo da Escola Nova, do vitalismo filosófico, da Gestalt e aínda do condutismo e do construtivismo psicolóxico. Mediante a construción e renovación dunha dinámica rede de profesorado presente no conxunto do territorio francés e en diversos estados e nacións (desde o Xapón ao Senegal, desde México ata Italia) a Pedagoxía Freinet continua sendo hoxe unha orientación innovadora e de futuro, ao dar vida a valiosas prácticas escolares. O presente texto procura realizar unha presentación global e sistemática desta orientación pedagóxica, tendo en consideración a súa evolución no tempo e como actualmente se define, ao ter considerado tanto as análises críticas realizadas desde o pensamento pedagóxico que a analiza, como o seu propio dinamismo.

Palabras chave: Pedagoxía Freinet; renovación didáctica e innovación; reforma social e escola; protagonismo infantil.

\section{ABSTRACT}

Célestin Freinet, who had extraordinary intellectual, emotional and social pursuits, developed an intensive pedagogic action between 1920 and 1966. He did it with an ability to renew the schools as he proposed new tools and techniques as well as learning resources and new approaches of educational philosophy, through intensive practical experimentation, constantly reflected upon and theorized, and

Recibido: 18/IX/2019. Aceptado: X/2019

1 Unha versión primeira e sintética do presente texto co título "Historia e actualidade dunha pedagoxía" vén de ser publicada como Epílogo á edición galega da obra de C. Freinet (2019): As técnicas Freinet da Escola Moderna. Tivemos ocasión de escribir arredor da pedagoxía Freinet diversos textos en Costa Rico (1997, 2010, 2011a, 2011b, 2012, 2016). 
creating a fusion with factors of the socialist school beliefs, Dewey's pragmatism, the activism of the New School, philosophical vitalistic theories, the Gestalt and even of the psychological behaviorism and constructivism. Through the development and renewal of a dynamic network of teachers in the French territory and various other states and nations (from Japan to Senegal and from Mexico to Italy), today Freinet's psychology continues to be an innovative and forward-thinking approach, as it gives rise to valuable school practices. This text try to make a global and systematic presentation of this pedagogical orientation, taking into consideration aspects such as: its evolution across time or the way in which it is currently defined (having considered both the critical analyzes carried out from the pedagogical thought that analyzes it, as its own dynamism).

Key Words: Freinet's pedagogy; didactic renewal and innovation; social and school reform; child protagonism.

Para as investigadoras e investigadores

que compoñen o Grupo de Investigación

SEPA-interea da USC, que se moven entre as

limitacións das políticas universitarias e o

horizonte onde nacen outros posibles.

\section{DE ONTE A HOXE}

Un lugar singular dentro das reformas pedagóxicas do século XX corresponde aos mestres franceses Célestin (1896-1966) e Élise Freinet (1898-1983) quen, desde a óptica do paidocentrismo e desde as influencias próximas de Ferrière, Decroly e de Kerchensteiner, quixeron realizar as propostas máis avanzadas da Escola Nova no campo das escolas públicas, cun horizonte de construción da sociedade socialista ${ }^{2}$. Eran mestres de escola, un feito case excepcional entre os reformadores da época. E non procuraban só unha pedagoxía activa nas súas clases, senón tamén a transformación social, comezando pola contorna escolar.

Acreditando no potencial de vida e no dinamismo natural, ao soster que "a educación é desenvolvemento e elevación", Célestin Freinet pretendía facer das escolas públicas laboratorios de traballo, de observación e de experimentación, onde as necesidades vitais e de saber de todas as crianzas atopasen resposta, nunha atmosfera de cooperación e de traballo-xogo, mediante o uso de técnicas didácticas como o texto libre, a imprenta escolar, o xornal escolar, a correspondencia, o debuxo libre, os estudos do medio social, os libros de vida —en substitución dos libros de texto-e os estudos científicos.

2 Este texto está construído coa achega dun importante aparato crítico, mais non só. Contéñense modulacións que en diversas ocasións son debedoras dos diálogos que se sosteñen na lista electrónica de asociados a Les Amis de Freinet (https://asso-amis-de-freinet.org/), que seguimos, e na que con frecuencia participan case unha trintena de nomes en masculino e en feminino, que habitualmente representan itinerarios educadores de bastantes décadas, podendo así ter coincidido con Célestin Freinet e sobre todo con Élise Freinet. Pour tous et toutes les ami/es mon profond reconnnaissement. 
Unha escola cunha metodoloxía activa, mediante técnicas didácticas que Freinet formula como técnicas de vida, é dicir, como medios eficientes para abordar as situacións vitais e os problemas de desenvolvemento dos nenos, a partir do protagonismo concedido aos textos libres como punto de arranque, de motivación e de interese.

\section{O ITINERARIO VITAL —COMPARTIDO— DE CÉLESTIN FREINET}

Célestin Freinet naceu o 15 de outubro de 1896, en Gars, pequena poboación montañosa e rural da Provenza. A súa xuventude transcorre entre os traballadores do campo, nunha rexión pobre e de clima duro: el mesmo pastorea ovellas e realiza outros traballos campesiños, o que impregnará de múltiples referencias e exemplos a súa posterior produción escrita pedagóxica, na que de seguido se alude a imaxes da natureza e da vida campesiña.

Ingresa con dezaseis anos na Escola de Maxisterio de Niza, onde realiza só dous cursos ao ser mobilizado militarmente con ocasión da primeira guerra mundial: recibe formación militar e en 1916 é enviado á fronte de combate ata que no outono de 1917 a metralla desfaille o tórax, o que lle ocasiona unha pleuresía severa da que nunca se curará completamente, e durante toda a súa vida posterior respirará mal, polo que lle atribúen unha importante invalidez ${ }^{3}$. A experiencia da guerra e o contacto coas ideas do internacionalismo proletario e con lecturas que lle abrían o horizonte cara a prácticas renovadoras da educación tradicional irano levando cara os idearios sociais progresistas, que pon en práctica no seu pobo natal, Gars, a través do impulso a unha cooperativa de produción e consumo e dun sindicato, con outras iniciativas.

Rematados os estudos de Maxisterio, en 1920 consegue un posto de profesor na escola rural de Bar-SurLoup, nos Alpes marítimos, nunha zona de vales, montañas e oliveiras. Aquí constata a súa incapacidade para instruír aos nenos mediante os métodos tradicionais coas frías leccións dos libros de texto único, os exercicios de memoria, os exames de repetición ou as longas explicacións, polo que improvisa algunhas actividades distintas: escoitar o que contan os nenos desde as súas experiencias de vida e escribir algunhas daquelas narracións no encerado; como escribiu Élise Freinet (1975: 25):

En contacto cos nenos comprendeu definitivamente que tiña que buscar nas súas vidas os novos elementos do seu traballo pedagóxico, apoiándose no seu interese por cada cousa, para satisfacer a súa necesidade de actividade, gran novidade maxistralmente descuberta por Ferrière en $L^{\prime}$ École Active ${ }^{4}$.

3 Recentemente foi publicada unha monografía (Saint-Fucsien, 2017) sobre o tempo da guerra e as súas consecuencias posteriores para Freinet; un texto polémico, con indicacións informativas valiosas, pero con inconsistencias relativas á contextualización educacional de Freinet, do seu pensamento e obra.

4 Élise Freinet publicou en 1949 Naissance d'une pédagogie populaire, traducido ao castelán en 1975, un texto fundamental para o coñecemento das dinámicas e experiencias que foron conducindo á configuración da pedagoxía Freinet. Un texto que a propia Élise completou posteriormente (1981, na edición castelá) coa obra La escuela Freinet. Los niños en un medio natural. A historiografía máis recente procedeu a precisar algunhas das informacións aquí contidas. 
Afíliase á Federation de l'Enseignement Unitaire, organización sindical progresista, e escribe desde 1920 en L'École Emancipée, cunha visión da educación e da escola formulada desde a esquerda política ${ }^{5}$. Comeza daquela a familiarizarse cos grandes autores da pedagoxía incluíndo os da Nova Educación: os humanistas do XVI Rabelais e Montaigne; Rousseau e Pestalozzi; María Montessori, Cousinet, Decroly e Makarenko, sendo a Escola Activa de Ferrière, o texto que máis o influíu como indicou (1959: 4): “cos seus libros L'École active e La pratique de l'École Active, a atención permanente demostrada cara ao noso traballo e os seus constantes consellos, foi quen máis influenciou a orientación destes esforzos".

A través da vía sindical participa en encontros pedagóxicos en Hamburgo no ano $1922^{6} \mathrm{e}$ toma contacto con pedagogos alemáns do tempo renovador da República de Weimar, en particular con Petersen, o impulsor do Plano de Iena (Go, 2018: 58); incorpórase ao Groupe Français de l'École Nouvelle (GFEN) —que impulsa Cousinet, xunto coa publicación La Nouvelle Éducation que co-dirixe con M. Guéritte-, e en 1923 participa no Congreso da Liga Internacional da Nova Educación (LIEN) en Montreux (Suíza) onde contacta con Adolphe Ferrière, o impulsor da Liga desde 1921 —e da publicación Pour l'Ére Nouvelle — e pode escoitar as intervencións de moi destacadas figuras: Claparède ${ }^{7}$, Bovet ${ }^{8}$, Cizek e Cousinet ${ }^{9}$, entre outros.

Sentía Freinet a necesidade de buscar na vida dos alumnos os elementos do traballo pedagóxico, apoiándose sobre os seus intereses profundos para satisfacer a necesidade de actividade. Polas tardes a escola abríase á vida da vila e á volta dos paseos escolares, os nenos redactaban

5 L'École Emancipée era a revista sindical da Federation creada en 1919, onde Freinet insertou ata 1932, entre outros, os textos "Capitalisme et culture" (22.V.1920), "L'Internationale de l'Enseignement" (23.X.1920), "Pour la revolutión à l'école" (12.III.1921), "Comment ratacher l'école a la vie" (7.V.1921), "Contre une pédagogie syndicale" (4.VI.1921), "De 1'enseignement de 1'Histoire d'après J. Dewey (L'école et l'enseignement)" (25.V.1924).

6 Cando Alemaña estaba configurada como a República de Weimar e era escenario de numerosas experiencias pedagóxicas, entre as que sobresaían as escolas de Hamburgo e o plan de Petersen en Iena, tal como podemos examinar en J. R. Schmidt (1973), un texto inicialmente editado en francés en 1936.

7 Mostrouse Freinet sempre favorable á concepción funcional da educación teorizada por Claparède, desde Xenebra. Este en concordancia con John Dewey, reclamaba a funcionalidade da educación, isto é, a conexión dos procesos formativos escolares coas vidas infantís, dando resposta as súas necesidades de saber e de crecemento. Dedicou a esta cuestión o seu libro L'éducation fonctionnelle (1931); usaba con frecuencia a fórmula "que toute leçon devrait être une réponse", como escribiu nunha carta que lle dirixiu o 12 de febreiro de 1935 ao inspector galego e presidente da Sección de pedagoxía do Seminario de Estudos Galegos Manuel Díaz Rozas. Era profundo coñecedor dos estudos internacionais da psicoloxía experimental aplicada á infancia e foi impulsor desde 1912 do Institut Jean-Jacques Rousseau de Sciences de l'Éducation.

8 Pierre Bovet (1878-1965) foi director do Institut Jean Jacques Rousseau des Sciences de l'Éducation e con Ferrière e Claparède fundou na mesma Xenebra en 1925 o Bureau International d'Éducation, que Piaget dirixiu como organismo especializado da UNESCO en estudos de educación comparada. Foi autor de importantes textos sobre a educación ética e moral, o pacifismo e a educación.

9 O inspector de educación Roger Cousinet, que impulsou o GFEN desde 1922, foi creador do método de traballo libre por equipos, na procura de que as aprendizaxes se poidan construír coa axuda dos pares, cos que solucionar erros e compartir experiencias mediante os grupos. 
pequenos informes, tal como facían os nenos da escola de Jasnaia Poliana que no século XIX dirixira o escritor Tolstoi, unha experiencia coñecida entre os educadores europeos. Deste xeito estaba a punto de nacer a técnica didáctica do texto libre coa conexión entre a vida na aula e a vida exterior dos nenos.

Como darlle a esta presentación manuscrita dos textos infantís a 'prestancia' da letra impresa?; con este interrogante descubriu Freinet en 1924 o anuncio comercial da imprenta CINUP, cos seus compoñedores e caracteres metálicos, prevista para a impresión de prospectos; merca unha para experimentar e coa implicación dos nenos nacería a técnica da imprenta escolar, unha ferramenta que xa utilizaba Decroly en Bruxelas para editar Le Courrier de l'École, que Paul Robin e Cousinet ensaiaran ${ }^{10}$ e que contaba con antecedentes en América, como escribiu Dewey e traducimos (1918: 89-90):

Bastantes organizacións escolares estendidas por todo o país procuráronse unha máquina de imprimir, que é manexada polos alumnos con gran éxito. As máquinas instaláronse, non para ensinar aos alumnos as diferentes operacións deste oficio, senón para que os nenos puidesen por si mesmos imprimir algúns dos impresos, carteis ou outros papeis que necesita constantemente unha escola. Ademais do interese que os alumnos mostraron en manexar os tipos de imprenta, en facer funcionar as prensas e en editar os obxectos impresos, o traballo foi especialmente valioso no ensino do inglés. A composición de letras é un excelente método de exercicio en vocabulario, puntuación, construción de parágrafos e gramática, pois o feito de que o orixinal vai imprimirse dá un motivo para eliminar erros que os exercicios escritos por un alumno para o seu mestre nunca dan. A corrección de probas é outro exercicio do mesmo xénero. En tales escolas a imprenta publica en realidade todo o material impreso que se necesita durante o ano, incluíndo vocabularios, programas e papeis escolares.

A imprenta ía ser para Freinet unha ferramenta para orientar a súa pedagoxía ao permitir entrar o pensamento do neno no contexto escolar: os textos libres, lidos en voz alta na clase e que nalgúns casos eran traslados a textos impresos coa cooperación de todos, serán o punto de arranque das aprendizaxes escolares como centros de interese, dos que viña falando Decroly, convertendo aos nenos (coa participación do mestre) en actores ${ }^{11}$ da súa propia educación. Mediante a imprenta, todos os días cada neno podía recibir un exemplar impreso dun texto libre previamente seleccionado e gardábao na súa carpeta para constituír o libro de vida da clase. Como se pode ver na Figura 1, as primeiras imprentas escolares cos rodos para entintar tiñan un tamaño reducido, para impresión de textos tamaño cuartilla e así o podemos ver nos milleiros de xornais escolares conservados e arquivados en diversos centros documentais franceses.

10 A fins do século XIX Robin facíalle imprimir aos nenos na escola de Cempuis, cun interese de formación profesional, e Cousinet fixo que un editor imprimira textos infantís.

11 'Autor' e actor' son dous conceptos reclamados como definitorios do desexábel protagonismo infantil e xuvenil na aprendizaxe no presente da Pedagoxía Freinet. 


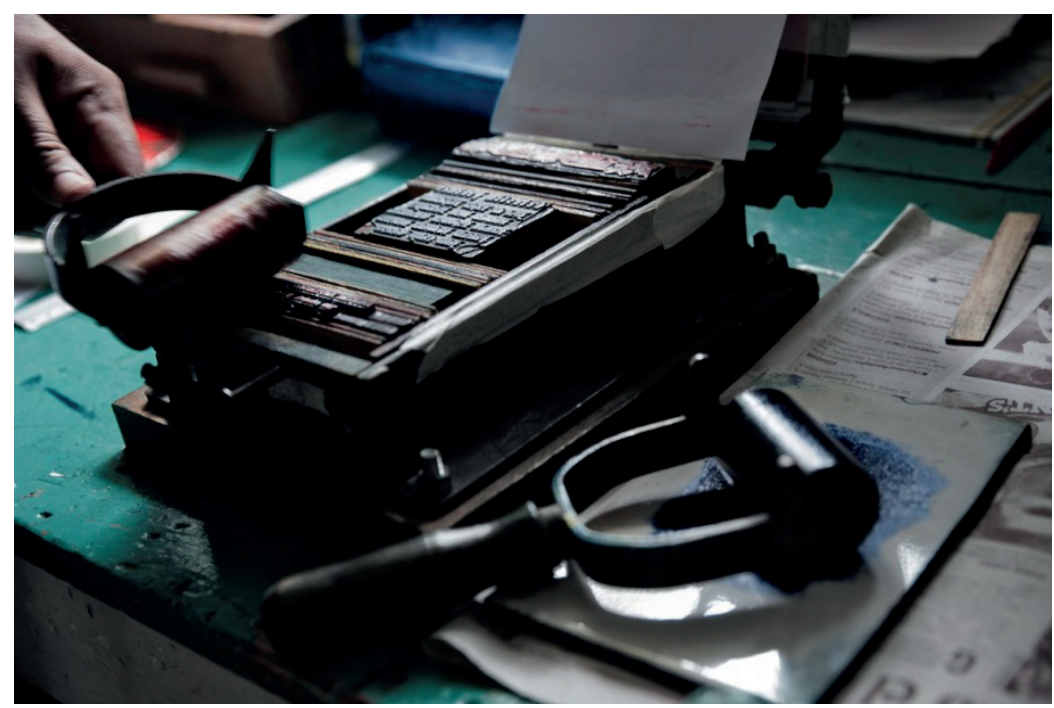

Figura 1. Imprenta escolar. Fonte: arquivo Antón Costa.

A dispoñibilidade dunha imprenta escolar, con rodos, tinta, papeis e linóleo para a práctica das ilustracións (Vid. Anexo1) ía xerar novos interrogantes de acción: un deles, a necesidade de dispoñer dalgún recursos económicos, polo que Freinet procurou converter a clase nunha cooperativa escolar, á imaxe dunha cooperativa de adultos, unha proposta que xa viña existindo en moitas escolas francesas a través da orientación dada polo inspector republicano progresista Barthélémy Profit, se ben el modifica o seu sentido último (Pelletier, 1997: 101-110) ao pensar na reunión da cooperativa de aula como medio de educación de contido ético, por medio dun regulamento aprobado entre os nenos e o profesor: así, a asemblea ou reunión de cooperativa servirá para o exame da vida do grupo, a planificación de accións, a toma democrática de acordos e o nomeamento de responsables de tarefas, incluíndo a presidencia rotativa das asembleas ${ }^{12}$.

\section{Un itinerario vital e carismático acompañado de camaradas}

Seguro Freinet da calidade e potencialidade destas innovacións didácticas, informa sobre elas nas páxinas das revistas L'École Emancipée e Clarté ${ }^{13}$ (Chabrun, 2016), ao tempo de defender

12 A cooperación como instrumento de educación estaba presente en Profit, como tamén na institución creada ao efecto, a Office Central de la Coopération à l'École (OCCE) e na publicación periódica Animation et Éducation, sendo frecuente na actualidade a colaboración en Francia entre os ensinantes do ICEM freinetiano e os ligados á OCCE.

13 Clarté foi unha revista de pensamento impulsada desde 1919 na área do Partido Comunista Francés por Henri Barbusse e nela Freinet insertou diversos textos: "Vers l'école du proletariat", "Les instituteurs allemands" (15.II.1923), "Pestalozzi, éducateur du peuple" (1.IX.1923), "La morale laïque" (5.V.1923) e "Vers l'école du proletariat: la dernière étape de l'école capitaliste" (1. VI.1924). Unha parte destes textos e dos publicados en L'École Emancipée foron reunidos nunha edición recente (Chabrun, 2016). 
posicións sociais transformadoras e antimilitaristas (Fuentes, 2017) e comeza a sentar as bases dunha técnica pedagóxica nova, ao tempo que promove unha publicación que acolle os textos dos nenos pioneiros, La Gerbe, que intercambiaba con outros mestres de distintos lugares de Francia, comezando así a correspondencia interescolar, unha práctica pedagóxica presente previamente nos Estados Unidos, como nos informou o pedagogo arxentino Ernesto Nelson (1905: 680): "Los niños de EEUU se comunican entre sí o con niños de otros países, se cambian retratos, remiten juguetes, tarjetas postales, productos nativos"14. De fundamental importancia foron para Freinet os primeiros intercambios desde 1926 coa escola de Tragunc na Bretaña e co mestre René Daniel.

En 1925 tería ocasión de viaxar á URSS xunto cunha delegación sindical da ITE ${ }^{15}$, coñecendo alí as prácticas pedagóxicas de escola activa e de educación polo traballo ${ }^{16}$, que os educadores Makarenko e Pistrak e a ministra de educación Nadejda Kroupskaia impulsaban desde o coñecemento da filosofía educativa de John Dewey e da Escola Nova e desde as orientacións marxistas que querían facer da educación unha panca ao servizo da Humanidade libre e nova que se pretendía. Esta viaxe permitiulle a Freinet documentarse sobre a pedagoxía dos complexos de interese, que pretendían unha conexión orgánica do traballo escolar coas finalidades sociais atribuídas a este traballo, co horizonte da educación comunista (Dubreuck, 2017: 180), distanciándose do termo "centros de interese" de Decroly ${ }^{17}$; esta viaxe permitiulle, ademais, madurar a concepción dos consellos de cooperativa ${ }^{18}$ e os cartaces de parede: felicito, crítico, propoño.

No ano 1926 Freinet casou coa educadora e creadora plástica Élise Lagier-Bruno, quen sería contrapunto e apoio permanente da obra e das ideas de Célestin, senda tamén ela mestra en Bar-Sur-

14 Ernesto Nelson, que recibiu formación directa por parte de Dewey na súa estadía nos Estados Unidos, trasladou estas referencias á Arxentina e desde aquí chegaron, como tamén a imprenta escolar (no sentido indicado por Dewey) ás Escolas da Unión Hispano-Americana Val Miñor, de Gondomar, a través da influencia do pedagogo galego, institucionista e figura pedagóxica na Arxentina, Ignacio Ares de Parga, de quen falamos en distintos lugares Xosé M. Malheiro Gutiérrez e eu mesmo.

15 A Internacional de Traballadores do Ensino, fundada en Francia en 1920, agrupou pronto aos sectores sindicais do ensino de orientación progresista en toda Europa. A Federación Española de Traballadores do Ensino (FETE-UGT), que integrou no tempo da II ${ }^{\text {a }}$ República a case 700 ensinantes en Galicia, todos con orientacións políticas progresistas parcialmente diferentes, tamén os galeguistas, formou parte da ITE. Entre o profesorado galego exiliado en México logo do 36 destacou polo seu labor sindical e representante da ITE en México, Luís Soto Fernández.

16 Deixouno reflectido en 1927: Un mois avec les enfants russes (con fermosos gravados de Élise Freinet). París: Edition de Les Humbles; un texto ao que acompañou outro de Maurice Wullens, o director de Les Humbles: París-Moscou-Tiflis. Despréndese do texto unha valoración favorable dos servizos complementarios ás escolas —os círculos de rapaces e pioneiros coas súas actividades-, pero non en canto ao estrito funcionamento escolar.

17 Freinet inspírase nos centros de interese de Decroly, mais non era partidario dun programa escolar preestablecido, ao considerar que non existen centros de interese comúns e previos para o alumnado; por iso habería que suscitar tales centros desde os intereses infantís. A proposta dos "complexos de interese" procuraba, pois, promover 'centros de interese' suscitados a partir dos episodios vitais das crianzas.

18 A proposta dos consellos de aula estaba presente en Cousinet, en Decroly e noutros educadores da Escola Nova, ligándoa á idea do self-gobernment que se practicaba como un medio de educación moral, mediante a aprobación de regras de vida do grupo (Ao respecto: Ferrière, 1921). 
Loup. Neste ano ingresaron os dous no Partido Comunista francés, mentres se ampliaba a outros mestres a rede de colaboración emprendida.

No 1927 Freinet publicaba o texto L'imprimerie a l'école $e^{19}$, mentres preparaba imprentas adaptadas para un traballo escolar que se estendía. Élise, pola súa parte, inicia a publicación Enfantines e celébrase en Tours, aproveitando o congreso sindical, o primeiro congreso da Imprenta Escolar no que participan uns 40 mestres, entre eles o español Manuel Cluet Santiveri, profesor na Escola de Maxisterio en Lleida ${ }^{20}$. En 1928 Freinet fundaba a Cooperative de l'Enseignement Laïque (CEL) para a edición do material didáctico (outils) que preparaban os profesores que e coordinaban, aparece o boletín mensual L’imprimerie a l'école e algúns entre eles crean unha cinemateca cooperativa, usando nas escolas pequenas cámaras Pathé-Baby: así, mediante o intercambio de filmes mudos penetraría o cine en moitos lugares da Francia rural ${ }^{21}$.

Daquela Freinet, mestre agora en Saint Paul de Vence, fora designado delegado e conferenciante para o Congreso Pedagóxico Internacional de Leipzig, por parte da sección francesa da Internacional do Ensino. Prepara o folleto Plus de manuels scolaires e en 1929 lanza o proxecto de Ficheiro Escolar Cooperativo (FSC), como complemento dos textos libres, mentres nas clases utiliza as BT (Bibliothéque de Travail), unidades documentais que comezan a ser editadas en $1932^{22}$.

Por outra parte, investiga Freinet o que será chamado o "método natural de lectura e escritura", inspirándose no "método global" de Decroly, a través da observación da conquista da lectura e da escritura por parte da súa filla pequena Baloulette e publica La Grammaire en quatre pages. Lanza o Ficheiro auto-correctivo de cálculo ${ }^{23}$ a partir dos problemas que os nenos viven e en 1932 cambia a cabeceira da revista L'Imprimerie à l'École pola de L'Éducateur Proletarien ${ }^{24}$; neste ano xa había

19 Un dos exemplares desta edición (Boulogne: Ferrary editeur), dedicado por Freinet ao mestre portugués Cesar Porto, foi localizado por nós nun alfarrabista de Lisboa en 1985. Cesar Porto foi compagnon de Freinet na ITE e un dos que viaxou á URSS na delegación internacional de ensinantes de 1925. Este exemplar forma parte hoxe, por doación nosa, dos fondos patrimoniais do Movimento da Escola Moderna (MEM) de Portugal. Nos fondos da Biblioteca Díaz Rozas, que localizamos en 1990 e que están actualmente depositados na Cidade da Cultura en Santiago, existe felizmente outro exemplar desta edición.

20 Exiliado posteriormente en Venezuela.

21 Un sistema de cine amateur fabricado e comercializado pola empresa francesa Pathé Frères a partir de 1922. Constaba dunha pequena cámara e un proxector de sobremesa que funcionaban con película perforada de 9,5 $\mathrm{mm}$. (en $16 \mathrm{~mm}$. desde os pasados anos cincuenta). O seu pequeno tamaño e o innovador e asequible formato da película fixeron moi popular este sistema nos anos 20 e 30 do século XX. Entre os primeiros filmes realizados encóntrase Le petit port de Trebignon, como parte da correspondencia entre a escola de René Daniel na Bretaña e a de Bar-sur-Loup.

22 En 1981 o número de profesores abonados ás edicións de BT chegaba á cifra de 10.000; en 2006 a colección documental editada chegaba ao número 1181. A súa beira foron nacendo distintos complementos: $S B T$, desde 1957; BT Son desde 1960; BT Junior desde 1965 (para nenos de 8 a 11 anos), con cinco números por anos, que acadaba en 2008 a cifra de 522 unidades documentais; e BT2, desde 1968, para escolares dos liceos.

23 A CEL publica tamén ficheiros autocorrectivos progresivos que serven para que cando un escolar remata un exercicio, el mesmo poida examinar se os seus resultados son correctos.

24 Cando esta publicación reapareceu en 1945 foi como L'Educateur, cabeceira que pasará en 1988 a ser $L e$ Nouvel Éducateur, que actualmente conserva. 
en España un pequeno grupo de mestres influenciados por Freinet, sobre todo en Cataluña; entre eles, o inspector de educación Herminio Almendros ${ }^{25}$. Desde a URSS ata Portugal, desde Dinamarca a Bélxica e sempre cara a Francia: a correspondencia interescolar (cartas e paquetes postais) será un feito dinámico e vivo...con crianzas aprendendo aspectos de diversas latitudes, coa axuda de mapas e de dicionarios para os intercambios lingüísticos e mediante o uso frecuente do esperanto, ao coidado de N. Bourguignon ${ }^{26}$.

O enfrontamento suscitado coas autoridades locais e os sectores acomodados de Saint Paul de Vence, como consecuencia da orientación pedagóxica que o matrimonio Freinet imprimía á súa acción, levou ás autoridades locais a tratar de trasladar en 1933 a Freinet a outro lugar, conseguindo apartalo do ensino público, logo dunha etapa de duras diatribas alimentadas pola prensa conservadora francesa.

Naquelas circunstancias naceu no contexto da CEL a idea da creación dunha escola libre experimental que, coa axuda dos amigos e de militantes de esquerda, se poñerá en marcha n'O Pioulier - un lugar apartado e de media montaña separado da vila de Vence-, que abriu as súas portas en outubro de 1935; unha escola con internado ou pensionado mixto, proletaria e naturista ${ }^{27}$, que inicialmente apenas recibiu un reducido número de rapaces e rapazas, fillos de ambientes militantes parisienses; en todo caso, sería o lugar da práctica libre destas novas técnicas pedagóxicas.

Freinet tivo daquela ocasión de ser invitado para falar das súas técnicas na Escola d'Estiu en Barcelona, cidade esta na que se vai abrir unha Escola Freinet en 1936. Ademais, impulsa con Romain Rolland e Henri Wallon unha Fronte da Infancia, en defensa dos dereitos das crianzas e participa en diversas mobilizacións sindicais; adhírese á Fronte Popular e pon en marcha a Liga dos Pais Proletarios, fronte ás asociacións de pais de espírito reaccionario. Quería facer do movemento da nova educación un movemento de masas, polo que reforzou os lazos co Grupo Francés da Nova Educación, mentres a súa influencia francesa e internacional aumentaba.

25 O profesor mexicano Fernando Jiménez Mier y Terán (2007) investigou o primeiro núcleo destes ensinantes na provincia de Lleida, e seguiu os itinerarios dos exiliados logo en México.

26 Nos anos vinte-trinta do século XX había — como parte do internacionalismo obreiro e/ou masónico - unha corrente de opinión favorable ao dominio e uso do esperanto, que tamén se promovía desde o movemento escuteiro (boys scout's). Entre nós, na cidade d'A Coruña había un núcleo non cativo de esperantistas. En 1931 había 100 escolas francesas que correspondían con 150 estranxeiras: isto é, uns 5000 nenos intercambiaban 1000 cartas de grupo, 4000 cartas postais e uns 500 xornais escolares, xunto a outros diversos obxectos. Un 35\% coa URSS, un $26 \%$ con Alemaña, un $14 \%$ con España, un $5 \%$ con Inglaterra, un $45 \%$ con Bélxica, e un $3 \%$ con Suecia, entre outras realidades. Atendendo ás presenzas de nomes de ensinantes non franceses nos medios de información periódica freinetianos entre 1920 e 1939 detectáronse 44 nomes da URSS, 43 de Bélxica, 33 de España, 21 de Inglaterra, 18 de Suíza, 13 de Alemaña, 23 de Alxeria, xunto a outros dun amplo número de países.

27 Élise e Célestin Freinet emprestáronlle moita atención á saúde e á alimentación dos nenos presentes n'O Pioulier: unha boa saúde para aprender mellor. Introduciron diversas prácticas naturistas inspirándose no método do Dr. Brocho (Basile Brochopoulos), que incluía os baños en todo tempo na pía que hoxe aínda alí está. 
Daquela impulsou igualmente a colección editorial Brochures d'Education Nouvelle Populaire (BENP) para abordar asuntos pedagóxicos e didácticos que se suscitaban no marco dos debates didácticos da CEL, mesturando orientacións teóricas e exemplos prácticos, ao tempo de ser acollidos na escola de O Pioulier nenos españois fillos de familias republicanas, refuxiados, ata o fin da guerra civil (Costa Rico, 2010).
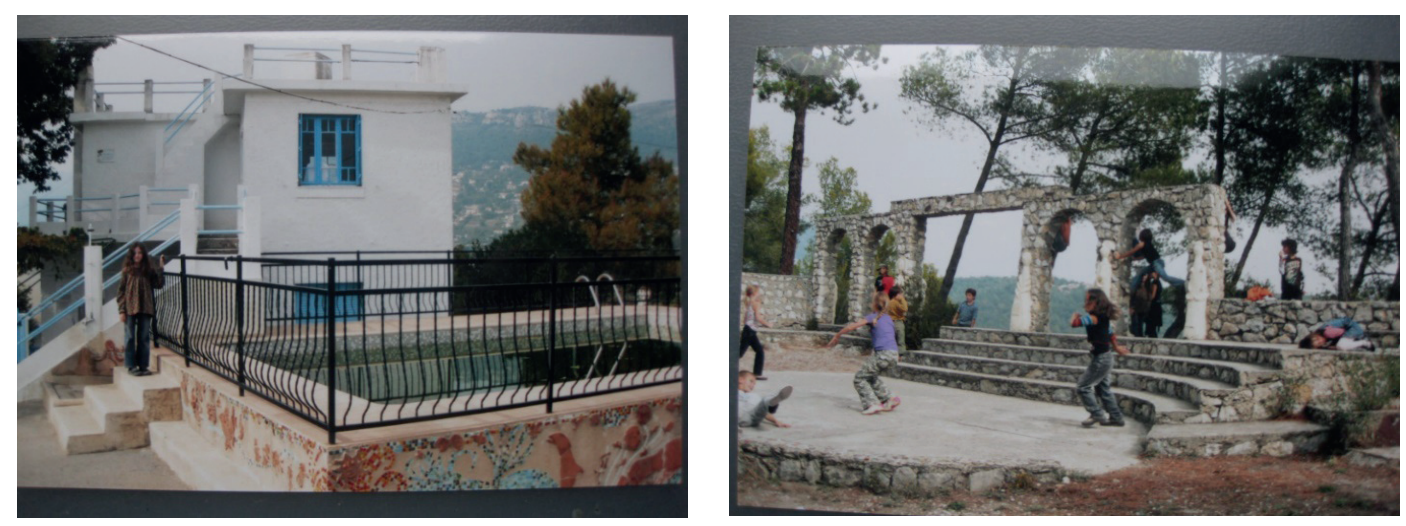

Figura 2. Á esquerda, podemos ver o primeiro dos varios edificios construídos para a escola en O Pioulier, coa pía de auga para os baños, e, á dereita, o espazo habilitado para o teatro e a danza. Fonte: 2008: arquivo Antón Costa.

En 1939, comezada a segunda guerra mundial, Élise e Célestin Freinet, como sospeitosos pola súa pertenza ao Partido Comunista, serían sometidos a vixilancia e en marzo de 1940 Freinet sería preso en campos de internamento un ano e medio; logo, ata a fin da guerra formará parte da resistencia, chegando a dirixir un maquis, mentres escribía Conseils aux parents, L'École Moderne française e os borradores de Essai de psychologie sensible e de L'éducation du Travail.

Rematada a guerra, Élise e Célestin volven ao Pioulier para abrir novamente a escolainternado —no que había 70 nenos e nenas e 6 adultos a fins de 1951 —28, que se converterá en escola-laboratorio (Barré, 1996; Go, 2007) e lugar de encontro docente, en particular no tempo do verán; reaparece a revista L'Educateur (1945) e saen novos folletos da Educación Nova Popular, mentres Freinet ensaia algúns procedementos recomendados nas classes nouvelles ${ }^{29}$. Da ao prelo en 1946 L'Education du Travail e L'École Moderne française e Élise, pola súa parte, La Santé de l'enfant. Entre tantas iniciativas farase en 1946 o film $L^{\prime} E ́$ cole buisonniere ${ }^{30}$, que quere retratar o seu exercicio educador.

28 Hai unha fermosa crónica da vida da escola nos pasados anos sesenta elaborada por Julieta Solís (2014: 55), onde esta ex-alumna fala de Freinet como "le papá Freinet, le coeur ardent".

29 O educador francés Gustave Monod, como Director Xeral de Ensino Secundario do goberno francés constituído en 1945, promoveu co directo apoio dpo GFEN en 140 Lycées a existencia de classes nouvelles, seguindo as orientacións do Plan Languevin-Wallon, o que facía posible o desenvolvemento de importantes innovacións didácticas ligadas ao espírito da Escola Nova e Activa.

30 A escola que pasea (traducimos) foi o film de 99 minutos que Jean Paul le Chanois dirixiu en 1949, narrando a vida dun mestre para o que se inspirou na figura de Célestin Freinet, con guión do propio Le Chanois, a partir dunha sinopse de Élise Freinet. A acción transcorre en 1920, nun pobo de Provenza, onde o 

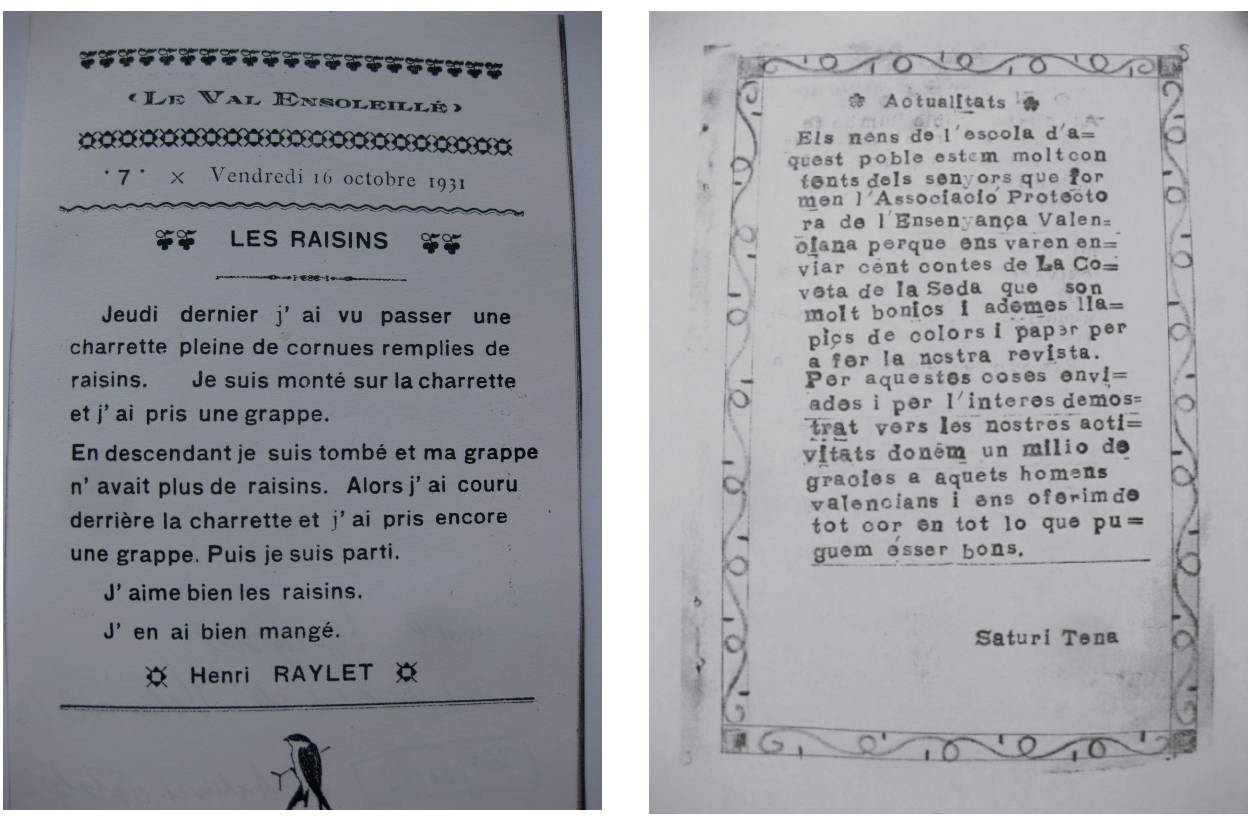

Figura 3. Textos libres impresos dos anos 30: en francés e en catalán.

Reinician, pois, unha intensa actividade para volver poñer en marcha o movemento de renovación pedagóxica. En 1947 volvía celebrarse un congreso da CEL e creábase o ICEM (o Institut Coopérative de l'École Moderne), que se organizaba en comisións nacionais e seccións departamentais, instalándose os dous organismos na cidade de Cannes retomando os distintos traballos: publicacións, encontros, grupos de traballo, preparación de materiais... Como nova iniciativa ponse en marcha un caderno de roulement entre os militantes ${ }^{31}$ e aparecen novas publicacións: Les méthodes naturelles dans la Pedagogie Moderne (1947), Le Journal Scolaire (1957, con edición renovada e póstuma en 1967), Les Dits de Mathieu (1959) ${ }^{32}$ ou Les Techniques

novo mestre, señor Pascal, introduce cambios na docencia: escoita os nenos, inspírase nas súas descubertas, valora as súas capacidades e andan en contacto coa natureza.

31 Este caderno, que corría de man en man entre os ensinantes que formaban un taller de elaboración documental, segundo unha orde e calendario previsto, permitía que cada un puidera escribir as súas suxestións sobre unha cuestión dada, que lían e complementaban ou retrucaban os seguintes, madurando así un determinado punto de vista e información, que logo podía desembocar nunha posta a punto presencial. Cómpre sinalar que a práctica de organización de grupos de traballo, de experimentación, deseño e elaboración de materiais e recursos foi decantando condutas que se incorporaron mediante protocolos detallados de procesos aos chantiers d'elaboration des outils.

32 Unha reunión de textos escritos por Freinet, primeiro como editoriais, nos que fala da infancia, da aprendizaxe, do papel do mestre ou do vitalismo presente na ascensión e desenvolvemento da vida, facéndoo con imaxes e metáforas procedentes do mundo agrario e da natureza. Esta edición foi antecedida polas de 1949 e 1953; foi traducida ao castelán e publicada en 1970 en Barcelona pola editorial Estela, baixo o título Parábolas para una pedagogía popular. 
Freinet de L'École Moderne (1964), xunto aos textos que elabora tamén Élise e a nova edición en 1966 do Essai de psychologie sensible appliquée à l'éducation (1950) ${ }^{33}$.

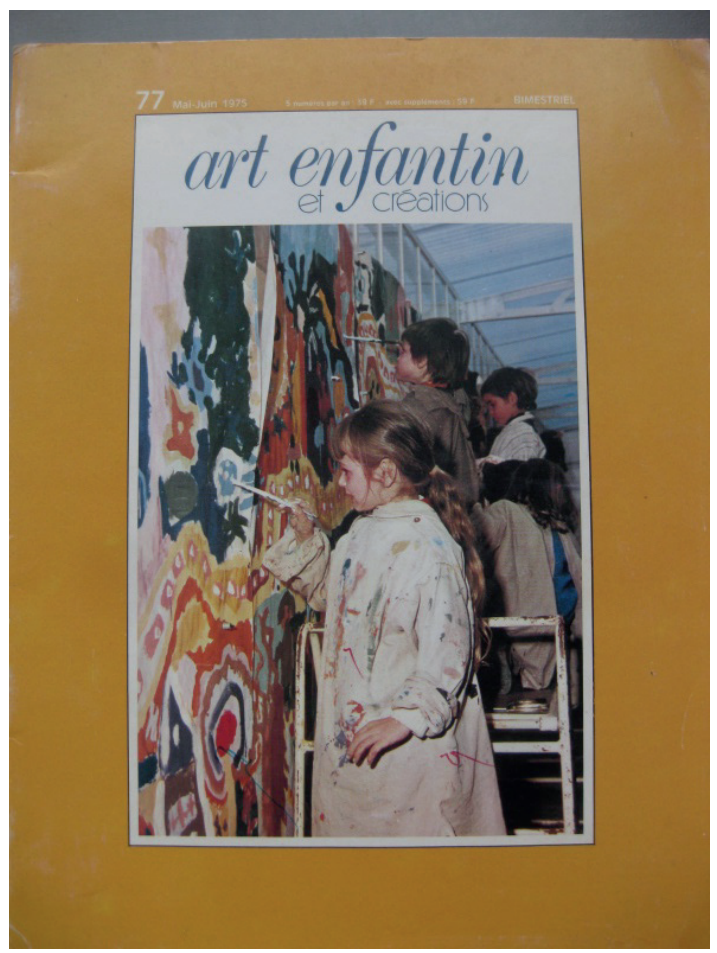

Figura 4. Portada da revista L'Art Enfantin et Creations.

Entre 1937 e 1953 aparecen máis de 80 folletos da Colección BENP, 25 deles escritos por Freinet, que foi autor, ademais, de moi numerosos artigos de revista (Bruliard, Schleminger: 57); entre 1960 e 1966 edítanse, ademais, 20 títulos da Biblioteca da Escola Moderna (BEM), ${ }^{34}$ entre eles Les Invariants pédagogiques, unha especie de código pedagóxico para os educadores Freinet. Cada quincena sae $L$ 'Educateur ${ }^{35}$. En 1958 lanza o ICEM a proclama " 25 alumnos por clase", acompañando

33 Que inclúe un Prefacio do propio Freinet con referencias á La formation de l'esprit scientifique de Bachelard (edición de 1965) e a Theillard de Chardin, a propósito de súa posición sobre o tenteo experimental. Hai nesta obra de Freinet rastros igualmente das críticas formuladas en 1927 por Georges Politzer á psicoloxía obxectivista, e do seu recoñecemento á importancia da psicanálise.

34 Vinte e dous dos títulos foron traducidos e editados en castelán e en catalán desde o comezo dos pasados anos setenta desde a editorial Laia en Barcelona.

35 A revista acadou en 1971 a cifra de 14.000 subscritores, aínda que os profundos cambios sociais vividos na década dos anos setenta, co seu reflexo no mundo escolar e docente, fixo descender rapidamente ese número a 8000 en 1975 e a menos de 1000 en 1996. 
a súa Charte de l'enfant. No 1957 créase a Federación Internacional de Movementos da Escola Moderna (FIMEM) e aparece a revista L'Art Enfantin et Creations (ver Figura 4), impulsada por Élise Freinet -que se editará como Creations até 2006-, quen tamén impulsa a creación do museo de arte infantil de Coursegoules; noutra orde de cousas, utilízanse e preconízanse desde 1964 as bandes enseignantes programmées autocorrectivas ${ }^{36}$, xunto aos procedementos audiovisuais ${ }^{37}$, os xornais, a correspondencia, as exposicións e os ficheiros de auto-corrección.

A intensidade de esforzos, de creatividade didáctica, de outils, como de reflexións foi moi notábel durante os anos sesenta-oitenta, como ilustrou Georges Delobbe: "singular reserva de imaxinación e de creatividade; lugar de confrontación e de formación"(2019: 47), arredor da perspectiva da escola como "lugar onde se aprende" con nítida prevalencia sobre a perspectiva do "lugar onde se ensina". Tamén na área das ciencias experimentais se rexistrou daquela unha inflexión, como manifesta a colección editorial de álbums Périscope.

É mester rexistrar igualmente un intento - pouco frutífero- de diálogo pedagóxico coas estruturas académicas e universitarias mediante a publicación Techniques de vie entre 1959 e $1962^{38}$, na procura de avanzar desde o empirismo pedagóxico cara a unha pedagoxía experimental, como salientou Élise Freinet no cumprido "Prólogo" ao preciso estudo biográfico histórico de Georges Piaton e na súa presentación de síntese da pedagoxía Freinet (1974 e 1977, respectivamente).

Entre tanto, a vida n'O Pioulier seguía: un espazo de vida, de formación, de desenvolvemento físico, emocional e moral, de traballo-xogo e de ledicia, onde a creación, a expresión e a comunicación se mesturan coa investigación e a experimentación, a través do uso dos ficheiros, dos libros, das BT, da imprenta e a correspondencia, dos paseos, dos inquéritos ...ou dos talleres (labores do campo, carpintaría, ferraría, tecido, construcións, mecánica, coidado de animais...) con leccións vivas a cada paso.

Hai que indicar que a vida do ICEM e da CEL tivo neste período algunhas crises non menores: entre finais dos corenta e primeiros anos cincuenta Élise e Célestin Freinet sofren ataques ideolóxicos por parte de destacados membros do Partido Comunista no que eles militaban ${ }^{39}$ acusándoos de falta de ortodoxia marxista; uns ataques que terminan tanto no abandono desta militancia política ${ }^{40}$ como

36 Bandes nas que se implicaron, con Freinet, Paul Desbaty e Maurice Beaugrand, en particular (Delobbe: 2019, 32) e que Roger Fabry transformou a partir de 1966 en Livrets programmés autocorrectifs confeccionados durante varios anos. Ao deixar de realizar estas bandas púxose maior atención na realización de instrumentos autocorrectivos.

37 Ensaiados, en particular, por Michel Pellisier e Pierre Guerin.

38 Co título completo Techniques de vie. Les fondements philosophiques des techniques Freinet. No seu primeiro número escribiron Ferrière e Dottrens, entre outras destacadas autorías. O mundo universitario foi, agás contadas excepcións, pouco receptivo ás posicións de quen foi sobre todo considerado un empirista e non un 'científico', escondendo aí o desapego académico burocrático. Sobre a cuestión detívose recentemente Philippe Meirieu (2015: 15-18). A propósito, é do caso sinalar unha continua referencia favorable á pedagoxía Freinet nos numerosos e valiosos textos de $\mathrm{Ph}$. Meirieu. Os Freinet mantiñan unha posición antiestalinista, que compartían con diversos camaradas libertarios.

40 Isto ocorre en 1950, logo de debater con Seclet-Rioux, ante os ataques recibidos de George Snyders, Garaudy e Cosniot a través de La Nouvelle Critique e L'École et la Nation, por considerar estes que a 
na separación do GFEN (Testanière, 1989: 63-83). Houbo, ademais, momentos de dureza económica para a CEL — unha cooperativa, ao fin — nun entorno de economía capitalista e de lucro empresarial, con algunhas consecuencias relacionadas coas tomas de decisión, que ocasionarían o fin da CEL en 1986, a pesar do seu extenso patrimonio de milleiros de documentos editados, que en parte recolleu o propio ICEM a través das actuais Publications de l'Ecole Moderne Française (PEMF).

Tamén na fin dos anos cincuenta se suscitaron no ICEM algúns debates psico-pedagóxicos en relación con cuestións notábeis: a práctica da pedagoxía Freinet en medio urbano, a psicanálise infantil, as orientacións terapéuticas, as propostas da 'non directividade' e a chamada autoxestión pedagóxica. A este respecto, á altura de 1962 aconteceu, debido a estes debates, unha creba organizativa que levou á sección parisiense do ICEM a abrir un espazo organizativo novo, o da Pedagoxía Institucional ${ }^{41}$.

O 8 de outubro de 1966 morría Célestin Freinet. Élise Freinet, pola súa parte, continuaría as diversas tarefas ata a súa morte en 1981, incluíndo a xestión da Escola Freinet; xestión que mantivo ata 1991 a filla, Madeleine Bens-Freinet. Neste ano a escola pasou a ser pública, con garantías de recoñecemento da obra de Célestin e Élise, mentres o ICEM, a asociación Les Amis de Freinet e a FIMEM continúan ata o presente actualizando os valores, os enfoques e o patrimonio pedagóxico que significa a pedagoxía Freinet ${ }^{42}$.

orientación pedagóxica vitalista freinetiana o separaba do socialismo (chamado) científico, dado que, segundo eles, descoidaba o rol esencial do mestre, subestimaba o valor dos coñecementos xerais en materia económica e social e non daba suficiente importancia á disciplina. Tamén Wallon participou neste debate con críticas á fundamentación psicolóxica freinetiana. Aínda en 1966 re-aparecerá esta posición ("militante anarquizante... anti-intelectualista... sen principios sólidos alén da experiénce tatonnée...") (SecletRioux,1966).

41 Foron promotores destas corrente Fernand Deligny, Fernand Oury e Raymond Fonvielle. A eles sumaríase pronto a psicóloga venezolana Aida Vasquez (1967). Vásquez e Oury indican que a Pedagoxía Institucional debía entenderse como un sistema de actividades, de mediacións diversas e de institucións escolares, para asegurar de modo continuo a obriga e a reciprocidade de intercambios, dentro e fóra dun grupo, a través non só de instrumentos e técnicas pedagóxicas, senón por medio de instrumentos conceptuais e institucións sociais internas capaces de resolver conflitos, mediante a facilitación permanente de intercambios materiais, afectivos e verbais. Neste sentido, Fonvielle profundou o protagonismo do consello da clase como institución e órgano de xestión colectiva.

42 En 1969 un amplo grupo de educadores ligados á pedagoxía Freinet constituíu a asociación Les Amis de Freinet, que se converteu nun gran espazo documental — reúne memorias vivas e un valioso arquivo-, que edita o Bulletín des Amis... (revista que supera os 103 números), na actualidade baixo a presidencia do profesor François Perdrial. O patrimonio material e de ideas freinetiano foi coidado, entre outros, por parte de Michel Barré (desaparecido en 1915 e con quen tivemos diversa correspondencia) en conexión co Musée Nationale d'Education en Rouen, ao reunir milleiros de unidades documentais de alto valor. Deben sumarse os notábeis fondos reunidos nos Archives Départementales des Alpes Maritimes en Niza - a partir do legado de Madeleine Bens Freinet-, os da Asociación Les Amis de Freinet en Mayenne (Bretaña), que coida Michel Mulat, os do Laboratoire de recherche en Sciences de l'Éducation de Lorraine, que promove diversas investigacións e a formación docente neste campo, así como, desde 2019, os da Médiathèque Élise e Célestin Freinet, ao coidado de Henri Louis Go, que protexe o concello de Vence. 

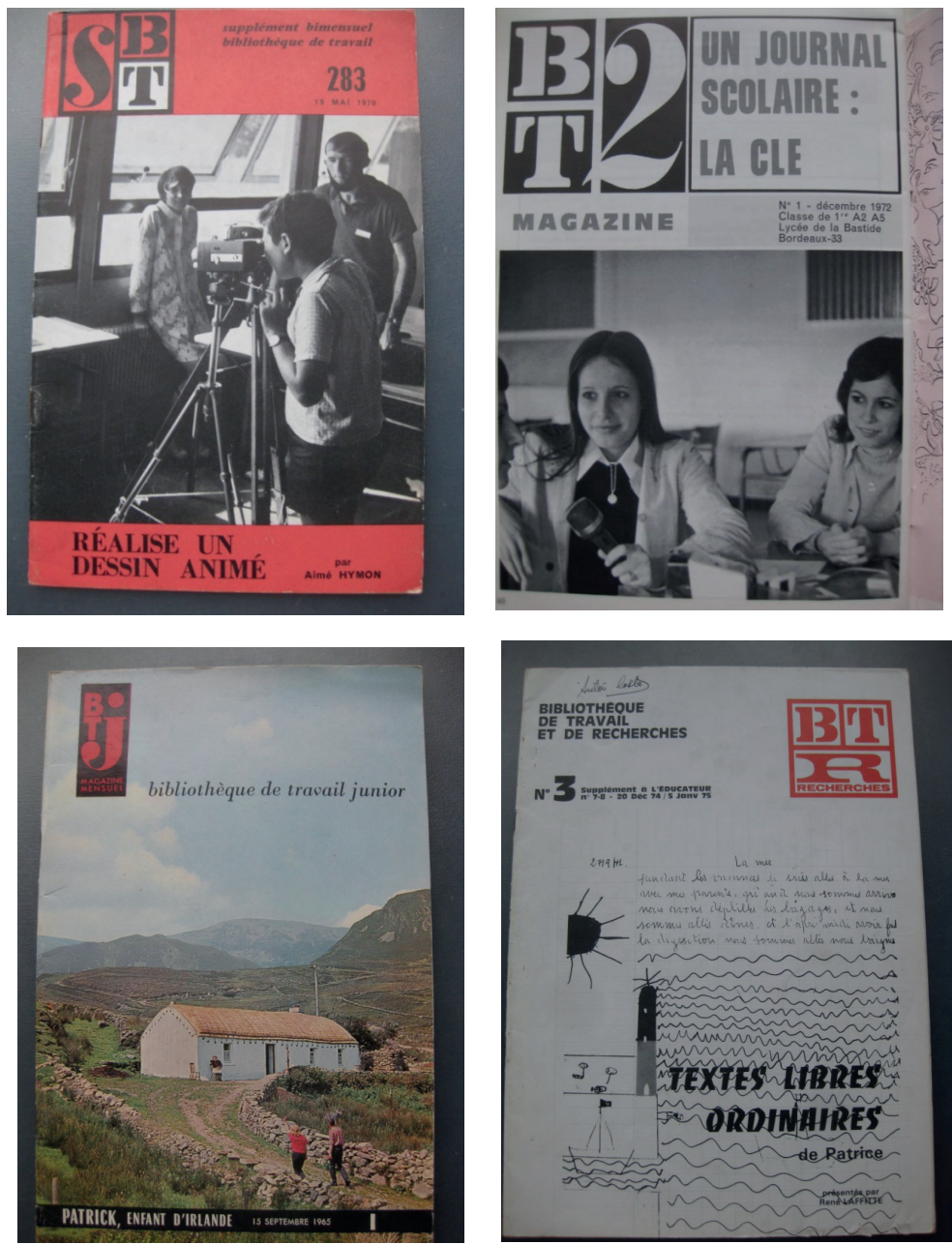

Figura 5. Distintas publicacións didácticas dos pasados anos 70.

Un momento singular de celebración e actualización tivo lugar en 1996, o ano do centenario do nacemento de Célestin Freinet: as diversas iniciativas emprendidas naquel ano (encontros, conferencias, exposicións e postas en común) tiveron un momento singular na celebración do XXXVI Congreso Internacional do ICEM en Antibes (Cannes) ${ }^{43}$ e outro no acto celebrado na UNESCO en París con 46 delegacións infantís doutros tantos lugares do mundo como recoñecemento ao significado internacional e pedagóxico desta orientación pedagóxica. Do mesmo modo, en 2016,

43 Actividade na que tiven ocasión de participar e que ademais me permitiu achegarme por vez primeira á escola Freinet en Vence, da man de Roger Byllé e do alxeriano Kader Bakhti; unha segunda ocasión ocorreu en 2008, establecendo contacto con Carmen Montés, daquela directora da escola. 
ao cumprirse os 50 anos da desaparición de Freinet, tiveron lugar diversas iniciativas, entre elas a elaboración dun número especial de Le Nouvel Éducateur baixo a coordinación de Catherine Chabrun, que articulou a historia e o presente desta pedagoxía.

A súa obra - escribiu Emile Thomas nos pasados anos oitenta- conservará a súa resistencia á destrución e o seu poder de conquista, na medida en que saiba multiplicar a súa riqueza interna mediante a posta en común dos recursos da obra colectiva; na medida sobre todo na que as ferramentas creadas (ou por crear) sexan utilizadas no espírito e para as finalidades que xustifican o seu uso de modo que, sen cesar, práctica e teoría se interpenetren.

\section{A PEDAGOXÍA FREINET}

\section{Supostos, principios, prácticas e técnicas}

A pedagoxía Freinet formúlase como unha pedagoxía centrada na crianza, que debe axudar a desenvolver o potencial de vida de cada un, a través dunha educación polo traballo, mediante unha metodoloxía natural que parte do tenteo experimental e do uso de técnicas pedagóxicas adecuadas, coa consciencia de que a intelixencia non é o motor senón o resultado. Unha pedagoxía que parte da tendencia natural do neno á acción, a expresarse, a crear e a exteriorizarse, que precisa para iso dun ambiente educativo que faga posible os procesos de aprendizaxe e a ampliación do horizonte escolar.

Os supostos freinetianos sitúanse na corrente da escola socialista, atendendo en particular a:

1. Á necesidade de elevar a formación dos sectores populares para adquirir os coñecementos científicos e culturais que lles permitan participar como actores plenos na construción social.

2. Á conexión entre as aprendizaxes escolares e as actividades vitais dos nenos a fin de que poidan percibir a súa utilidade e sentido.

3. Á apertura dos centros escolares en relación co seu contexto económico, social, cultural e político.

4. Á necesidade de xestión democrática entre o alumnado e o profesorado, podendo así participar, efectivamente, nas decisións referidas ao traballo e á organización do centro educativo.

Freinet é un militante social, político e pedagóxico (Houssaye, 1997: 18) que considera —como escribiu en Por unha escola do pobo- ás e aos educadores conscientes como persoas socialmente educadas e activas, que loitan nas organizacións sociais, sindicais e políticas, na preparación do terreo favorable ao traballo escolar, e en tal sentido define as súas prácticas pedagóxicas como unha Educación Nova Popular: trátase de que a escola promova unha nova concepción do traballo, coa superación dun restritivo sentido intelectual e moral, sendo para isto primordial dispoñer unha nova organización material escolar, de modo que o espazo da clase e o centro escolar anticipen a autoxestión social, ao servizo do que se institúen novas técnicas que permitan unir a escola e a vida. 
Sobre estes supostos, pódense establecer os seguintes principios pedagóxicos que Freinet identificou e formulou en 1964 mediante o texto Les invariants pédagogiques:

- Respecto á dignidade e confianza no neno, que implica partir dos dereitos de todos e cada un a expresar, crear, comunicar, esparexerse... situándoos no centro da escola en lugar do saber maxistral e adulto.

- A escola aberta sobre a vida exterior que os mesmos nenos incorporan, restablecendo a unidade da vida, mediante o método natural.

- O tenteo experimental que recoñece a permeabilidade á experiencia e a interrelación entre a teoría e a praxe.

- A educación polo traballo ${ }^{44}$ (Giauque e Christianat, 2015: 9) e a cooperación en tanto que necesidade de realización, que favorece a interiorización de diferentes procesos de regulación das persoas e do grupo.

- A personalización das aprendizaxes e a individualización do traballo no marco dunha dinámica de grupo equilibradora (Pain, 1997: 132), que respecta o ritmo propio de cada neno.

- A organización cooperativa que supón a asunción por parte do alumnado da xestión das súas actividades e das súas regras de vida... co acompañamento adulto docente, que exerce a súa parte de intervención, como salientan Jacomino e Rouvière (2014: 43).

Para o desenvolvemento pedagóxico de tales principios fóronse activando distintas prácticas pedagóxicas para favorecer:

- A expresión libre oral, escrita, corporal, estética... individual e colectiva, sendo un exemplo diso o inicio de cada día da escola mediante a pregunta: "Quoi de neuf?" (que novidades temos? $)^{45}$ para desencadear a apertura da primeira e inmediata comunicación aos demais, a través das manifestacións, interrogantes, sentimentos e impresións dadas a coñecer;

- o intercambio e a comunicación;

- o achegamento aos feitos e fenómenos mediante o tenteo experimental;

- a auto-organización e a asunción do traballo persoal, do traballo colectivo e das regras da vida da clase;

- o desenvolvemento persoal e colectivo do espírito crítico.

44 A reclamación que fai Freinet do "traballo-xogo", en lugar do "xogo-traballo" preconizado pola Escola Nova, apunta a experimentar unha concepción nova do traballo que procura nel o pracer do xogo e da aprendizaxe.

45 Funciona este interrogante, que é unha achega da Pedagoxía Institucional, como unha das institucións da clase. 


\section{Mediante diversas técnicas:}

- Os textos e debuxos libres, como expresión profunda dos nenos, de onde poder derivar unha rica e viva dinámica escolar, co uso da imprenta escolar actualmente substituída pola informática.

- O método natural de debuxo, escritura e lectura.

- A correspondencia escolar e as viaxes de intercambio.

- O xornal da clase e do centro e o libro de vida.

- O consello e as asembleas de clase coas súas regras.

- Os plans de traballo.

- As conferencias de aula.

- O cálculo vivo e a creación matemática ${ }^{46}$.

- O estudo do medio e os inquéritos.

- As monografías que compoñen a Biblioteca de Traballo.

- Os talleres ou obradoiros de expresión artística e de traballo manual.

- As árbores de coñecemento.

- Os ficheiros auto-correctivos.

- As bandas programadas.

Organizada a clase como taller ou conxunto de talleres, uns serven ao traballo manual de base e outros á realización de actividades de coñecemento, de experimentación, de creación, de expresión e de comunicación.

\section{Unha metodoloxía natural}

Freinet pensaba que toda a natureza estaba atravesada por unha forza vital ${ }^{47}$, que impulsa aos seres vivos a crecer e a perseverar, sendo esta forza a que preside a actividade natural dos nenos como motor das súas aprendizaxes, como se constata desde o Laboratoire de recherche coopérative de l'ICEM (2018: 141): un impulso que volve aos nenos curiosos e experimentadores;

46 A creación matemática, unida ao cálculo vivo, como un dos dispositivos do "método natural das matemáticas" enriqueceuse mediante as propostas de Paul Le Bohec nos pasados anos 60. Apóiase sobre a epistemoloxía das matemáticas e respecta os procesos de tenteo do alumnado: comeza coa construción dun problema; paso a paso o neno pode chegar á descuberta dunha noción, dunha técnica operatoria ou dunha lei matemática.

47 Baixo a influencia do pensador francés Henri Bergson que falou da "forza instintiva da vida" como o élan vital, un "torrente de vida" que impulsa a todos os seres humanos con boa saúde a realizar o seu potencial de vida, a aumentar as súas capacidades, para adaptarse o mellor posible ao medio e actuar sobre el. Freinet, como outros intelectuais do primeiro terzo do século XX, distante do materialismo positivista e de calquera mecanicismo, viuse influenciado pola posición do filósofo francés Henri Bergson, espiritualista e vitalista, quen na súa obra de 1907 L'évolution créatrice falou do élan vital, como unha forza ou impulso vital, hipotética, que provoca a evolución e o desenvolvemento dos organismos, e asentou sobre esta a súa elaboración do "método natural". 
é como os nenos aprenden a andar, a falar, é como as nais educan, como os científicos buscan e fan descubertas, como os escritores escriben... O esencial debe partir de cada aprendiz, sendo o contrario da artificialidade da escolástica e dos seus métodos tradicionais, e distinto da mera observación, explicación e demostración que parten do exterior cara o individuo.

Así, o modo de conquistar saberes ou o saber-facer é para Freinet o "tenteo experimental", segundo elaborou no seu Ensaio de Psicoloxía sensible (1950), como fundamento psicolóxico da aprendizaxe, que parte da natural «permeabilidade á experiencia»: un proceso universal da intelixencia humana, segundo o que as aprendizaxes se efectúan a partir das propias experiencias, da manipulación da realidade que efectúan os nenos —o que recorda a metodoloxía de resolución de problemas proposta por Dewey — ${ }^{48}$, da expresión creativa infantil e da organización cooperativa dun contexto próximo no que o alumnado poida formular e expresar as súas experiencias a través de mediacións técnicas adecuadas.

O neno experimenta de modo natural en todas as súas actividades ${ }^{49}$; evoluciona por ensaioserros ao azar cara a formas superiores e máis elaboradas (desde o tenteo empírico pásase ao tenteo metódico e científico), que constitúen a base dos métodos naturais de aprendizaxe, sendo o tenteo un proceso natural de aprendizaxes personalizadas, que implica tanto a acción como o pensamento, que se exerce en todos os dominios da actividade, que mobiliza os diversos procesos cognitivos e as operacións mentais habituais da intelixencia humana. Un proceso que, coa contribución de diversas técnicas, lle permite a cada individuo construír a súa cultura, nunha contorna dada, no seo dun grupo cooperativo co que se tecen lazos de aprendizaxe e de vida.

Os tenteos experimentais funcionan de xeito individual e colectivo de modo que permiten producir cooperativamente distintos saberes e a cultura da clase, facéndoo a través dun proceso que inclúe: os impulsos creativos e motivacións (a experiencia primeira); os ensaios; a emisión de hipóteses e a súa problematización; a verificación destas e a repetición dos actos logrados con éxito; a integración, conceptualización e avaliación, e, por fin, a modelización.

Estamos ante un proceso de aprendizaxe complexo, que engloba todas as técnicas Freinet fundamentais, que parte da acollida das producións libres dos nenos e procura a conquista dos saberes mediante a transformación destes produtos e o traballo cooperativo, tendo presente, como condición, que a necesidade de saber nace do obstáculo, da falta de comprensión e da busca que permita comprender e superar tal obstáculo; unha busca movida pola necesidade interior de saber e que pode incluír o erro. Tenteando, probando e rectificando apréndese, como indica a teoría clásica da aprendizaxe pauloviana, que Freinet revisa con dous supostos: o tenteo debe responder a unha necesidade do individuo (unha funcionalidade que lle da sentido e utilidade) e o seu éxito supón a memorización espontánea do proceso e a súa repetición ulterior en situacións parecidas, de tal modo

48 É posible facer unha lectura deweyana da pedagoxía de Élise e de Célestin Freinet: a experiencia como punto de partida e motivación dos intereses de aprendizaxe e do proceso problematizador cara a consecución do coñecemento.

49 Seguimos para esta exposición as entradas "Méthode naturelle", "Méthode naturelle d'écrit-lecture" e “Tátonnement expérimental”, en Laboratoire de recherche cooperative de 1'ICEM (2018: 238-253 e 346-347). 
que os éxitos destes tenteos son entón instituídos como "técnicas de vida", isto é, automatismos ou hábitos que o neno construíu por tenteo e que pode poñer en práctica diante de novas situacións.

\section{Método natural de escritura-lectura}

Seguindo esta elaboración, o método natural de escritura-lectura é, entón, o método natural ${ }^{50}$ de aprendizaxe da escritura e da lectura na pedagoxía Freinet; ao mesmo tempo, global e analítico. En 1934 Freinet, cando a súa filla Madeleine estaba no momento de aprender a ler e escribir, en lugar de darlle leccións tradicionais, deixaba que a nena pasara insensiblemente desde os seus debuxos comentados e desde a escritura dos nomes que coñecía ata a invención de pequenas historias, servindo de tránsito para a lectura 'de proximidade': coas distintas evidencias e ensaios de Madeleine reunidos redactou Freinet un informe que titulou Método natural de lectura.

Mostrou igualmente que existe o mesmo tipo de evolución no caso do debuxo dos nenos, coa condición esencial de non impoñer un modelo e de animalos a expresarse por medio do intercambio con outros. O método natural de lectura aborda en interacción constante o sentido e o código e fai indisociábeis as aprendizaxes da escritura e da lectura. En primeiro lugar, o neno debe ser posto en situacións de comunicación efectiva, porque estas situacións facilitan comprender que o escrito impreso produce sentidos a comunicar: isto é, o neno é produtor de textos que se comunican e o método natural parte da expresión primeira dos nenos e do seu desexo de comunicar, mediante textos de diversas clases e formatos.

De forma natural, grazas a unha familiaridade cada vez máis fina coas palabras escritas nos seus propios textos, á súa localización en textos referentes e ás comparacións (analoxía) feitas entre as palabras destes textos, os nenos comezan a dispoñer dunha mirada distinta sobre a lingua escrita que, entón, non é só portadora dun sentido, senón que tamén se convirte en obxecto de análise. Entran así os nenos nun proceso de comprensión progresiva do sistema ortográfico e do código alfabético, grazas ao traballo do grupo cooperativo: reunidos coa profesora neste proceso de aprendizaxe ante unha cartolina ou encerado tentean de modo cooperativo e ensaian descubrir o que algún deles escribiu.

A mestra debe animalos a observar e a sinalar todas as palabras que se parecen, a valorar as analoxías; que verifiquen con atención cada observación ata apropiarse das descubertas e podelas sistematizar mediante repertorios. Seguirá a apropiación do texto sobre o que se traballa para comprendelo e convertelo nun texto referente á vista de todos para poder servirse del coa intención de seguir avanzando na escrita, utilizando palabras, expresións e regras ortográficas implícitas. Así , formalízase a descuberta dos fonemas e do seu grafema correspondente, podendo dar lugar a exercicios de confirmación e de sistematización. A clase vai creando o seu manual de lectura.

As conquistas, inicialmente indecisas e globais, vanse pouco a pouco diversificando: desde o debuxo á escrita e á lectura (Cavinato, 1998: 27-35), porque a finalidade non é nunca pronunciar

50 Como mostra da actual confianza na metodoloxía natural o 54 congreso internacional do ICEM de 2019 salienta como lema congresual "Pour une méthode naturel à l'école publique". 
sílabas ou palabras, senón a de facerse comprender, e comprender aos que o rodean. Indica Freinet que só o sentido importa, e que son a creación e o poder compartir sentidos os mellores vectores do poder da vida, o que está habitualmente ausente nos libros de lectura coas súas frases separadas da experiencia individual e colectiva vivida.

Deste modo, o neno le e escribe mesmo antes de estar en posesión dos "mecanismos de base", porque accede á lectura por outras vías complexas, as da sensación, da intuición e da afectividade nun medio social favorable, a clase cooperativa: partindo da expresión primeira infantil como forma de recoñecemento e fonte de motivación, nun rexistro lingüístico próximo e afectivo da súa cultura. Este patrimonio cultural de proximidade constituído polos textos dos nenos permite realizar a conexión con textos da cultura común, podendo abordar desde aí e mediante o tenteo experimental a dificultade de lectura de textos producidos de modo máis distanciado e as normas da linguaxe escrita. Este método natural de lectura apóiase no texto libre e na correspondencia, que é a que da sentido perceptíbel e motivación á lectura e á escritura e á súa corrección máxima.

Freinet xeneralizará esta perspectiva de traballo, mostrando que o tenteo experimental está na base de todas as aprendizaxes e por iso deberíase favorecer a libre descuberta por parte dos nenos das grandes leis da linguaxe e da gramática, das matemáticas, das ciencias. A tal fin, sostén que é mester animar a realizar moitas experimentacións, que implican observar, comparar, imaxinar e verificar. Os diversos contrastes ata o presente realizados sobre este modo de proceder (Monceau, 1997: 43-56) sinalan que os nenos concéntranse máis e conservan un recordo duradeiro das súas descubertas, mentres que as aprendizaxes mecánicas se esquecen máis rapidamente.

\section{A expresión libre e creativa}

O proxecto educativo de Freinet non é o de transformar os nenos en escritores ou artistas, senón o de posibilitarlles o dominio de todos os modos de expresión. E como no caso dos textos libres non se trata de impoñer un tema 'de redacción', nin é tampouco a posibilidade de escribir un tema libre nun determinado tempo da xornada escolar ou un exercicio de mera espontaneidade, senón que se suscita como necesidade sentida (na clase ou fóra dela) de expresión de algo por parte das crianzas, sendo propiciada esta expresión por unha situación contextual e educativa que o favorece: "Un texto libre debe ser verdadeiramente libre. É dicir, que se escribe cando hai algo que dicir, cando se sinte a necesidade de expresar mediante a pluma ou o debuxo -Freinet,1960: 13aquilo que ferve no noso interior".

O texto libre libera o pensamento do neno (Clanché, 2009: 32), pode revelar o seu mundo interior e mesmo axudar a desbloquear posíbeis conflitos e ter por iso efectos terapéuticos (Bertheloot, Barré: 1980), tal como sinalou a Pedagoxía Institucional tomando en consideración as elaboracións da psicanálise infantil.

Os textos libres son a trabe de ouro da pedagoxía Freinet, salientou Jean Vial (1989: 16); desencadean unha moi rica actividade de aula como "lugar de vida": a lectura en voz alta dos escritos por cada neno, a escolla de aquel ou aqueles que poden centrar a actividade do día, a escrita do texto seleccionado no encerado ou na pantalla dixital, o traballo de todos sobre o texto que 
mobiliza diversas competencias lingüísticas, estéticas e sociais (redacción, ortografía, gramática, puntuación), a copia no libro de vida de cada neno, a súa edición como parte do xornal de clase, ou como envío de correspondencia e a súa ilustración gráfica. Un posíbel punto de partida para un centro de interese que pode favorecer procesos de investigación matemática, histórico-xeográfica, ambiental, ou doutro tipo ${ }^{51}$, que promove sempre unha nova relación adulto/nenos.

Élise Freinet encárgase, pola súa parte, de desenvolver o sentido artístico dos nenos que educan, sen habitualos a reproducir modelos: como no caso dos textos libres non hai que impoñer un tema, senón introducir diversas técnicas de traballo; así, para amplificar o xesto hai que pintar sobre grandes superficies con resultados sorprendentes, sendo importante que as creacións se expoñan, se discutan e se intercambien, a fin de buscar o modo de facer aparecer a orixinalidade de cada un. A propósito, Élise organizará diversas exposicións nos congresos pedagóxicos e en 1959 crea a revista L'Art enfantin, que se editou durante varias décadas.

\section{Un saber vivo para os grupos de traballo e para a individualización das aprendizaxes}

Cando a CEL comeza a editar os primeiros documentos da Biblioteca de Traballo (BT) apenas existían documentos para os nenos fóra dos libros de texto. A orixinalidade dos documentos da BT deriva da participación dos nenos: ás veces son os autores de enquisas ou investigacións publicadas in nuce nos xornais escolares ou en La Gerbe, singularmente no caso das reportaxes curtas. Frecuentemente estes documentos obedecen a novos proxectos de ciencias e técnicas, de historia, de xeografía, de problemas sociais e económicos.... (que son examinados en moitas clases, antes da súa publicación, para dar as opinións oportunas relativas ás dificultades de comprensión ou outros detalles), e foi deste xeito como estas unidades documentais se foron diversificando, mediante suplementos ou pensando en diversas idades, incluíndo a adolescencia.

En 1960 nacía, xunto ás BT impresas, a colección BT Son para recoller a experiencia das aulas referida á realización de investigacións sonoras co magnetófono $\mathrm{CEL}^{52}$ : os ensinantes aprenderon a facer montaxes, que permiten resaltar o esencial das entrevistas, e os nenos comezaron a entrevistar aos adultos que falan das súas infancias, aos artesáns, aos especialistas... acadando unha gran riqueza de testemuños editados baixo a forma de discos e casettes, acompañados de diapositivas e dun libro ilustrado.

Falamos, entón, do centro escolar como espazo para a elaboración dun saber vivo, que se desprende de tres condicións:

- Elabórase a partir das achegas da vida dos nenos e é aprehendido de modo dinámico e activo: quen aprende faino mediante un proceso guiado polo desexo de saber ou porque

51 Freinet, xunto con Dewey e Montessori, maniféstase en contra da sacralización do saber ('a escola como un templo') e defende que os nenos deben ser situados en posición de investigadores, con problemas escollidos por eles e co manexo de instrumentos útiles para coñecer mellor ('a escola como taller').

52 É posible acceder a unha altísima porcentaxe destes variados documentos a través dos fondos dixitalizados gardados por Encycoop en http://www.icem-pedagogie-freinet.org 
o ensinante soubo activar este desexo de aprender, mobilizándoo mediante a realización dunha produción ou dunha creación.

- Este saber é transferíbel fóra dos muros da escola e oponse aos saberes desconectados da vida.

- E porque son saberes vivos, tanto no momento da súa construción como no da súa utilización, evolucionan, precísanse, consolídanse ou póñense en cuestión en conexión con outros saberes que se constrúen en paralelo, en relación cos que se establecen pasarelas (Laboratoire..., 2018: 81).

Por outra parte, as aprendizaxes derivadas do manexo e construción de BT, que supoñen exercicios de tenteo experimental, deben ser acompañadas de exercicios sistemáticos que aseguren o adecuado dominio e progresión sen estar suxeitos a un percorrido único e a un ritmo imposto. Por esta razón, Freinet é quen primeiro utiliza en Francia para determinadas aprendizaxes os ficheiros auto-correctivos, que permiten o reforzo de automatismos e que cada neno traballe ao seu ritmo e faga as súas correccións ${ }^{53}$.

Así, foron publicándose ficheiros de operacións, de problemas, de xeometría, de ortografía e de conxugación; fichas-guías para facilitar as investigacións en ciencias, xeografía e historia, e cadernos autocorrectivos persoais, ata poñer a punto desde a perspectiva da programación nos anos sesenta as bandas programadas impresas con secuencias de desenvolvemento ( Freinet, 1964; Freinet, Bertheloot, 1966) ${ }^{54}$.

\section{Organización espazo-temporal e cooperativa da clase}

A clase Freinet incorpora unha nova organización espazo-temporal. O mobiliario e os materiais deben permitir pasar sen descontinuidade desde as actividades individuais ata as grupais, ou o contrario, e cómpre, pois, que sexa un espazo-taller con indicación de áreas de traballo e con disposición oportuna dos recursos. Un espazo articulado polos plans de traballo: o individual e de proxectos a realizar, o do mestre e o da clase, con distintas cadencias temporais, mediante unha xestión cooperativa.

Neste punto, Freinet pon en cuestión a autoridade única do ensinante, dado que todo o alumnado pode efectuar os diversos ritos escolares, o que non elimina o rol de adulto que axuda, dado que hai unha parte do mestre ou da mestra: esta sitúase ao nivel dos nenos e institúe momentos de intercambio (conversa da mañá, presentación e elección do texto a imprimir, posta a punto colectiva, posta en común de enquisas ou das buscas persoais).

53 Estas fichas, creadas ao servizo da auto-instrución e da lectura individualizada e sen libros de texto, eran unha das vías da individualización do ensino, que Freinet incorpora ao tomar en consideración, revisándoos, os modelos de fichas do sistema estadounidense de Winnetka. Con anterioridade, observou o traballo escolar por contrato, proposto no tamén estadounidense Plan Dalton, que valorou criticamente por intelectualista e pola taylorización do traballo escolar.

54 Refírese Freinet aos paquetes didácticos de ensino programado que se editaron seguindo as orientacións de acento pragmatista integradas na psicoloxía condutista, baixo a influencia do psicólogo B. Skinner. 
De modo cooperativo son tomadas cada semana un certo número de decisións. A cooperativa organiza progresivamente as distintas aprendizaxes, as interrelacións co medio e favorece a auto e socio-construción de saberes múltiples por parte de cada persoa, como expresou Le Gal (2013). Ademais, un xornal mural sobre o cal cada un pode escribir as súas propostas, as súas críticas, realizacións e felicitacións ("eu critico, eu propoño, eu felicito, eu realicei”) permite que todos os puntos de vista sexan tomados en consideración. Individualmente, cada alumno prepara no comezo da semana o seu plan de traballo e farase colectivamente o balance do realizado, ao tempo que os plans escritos permiten verificar se certos puntos do programa establecido non foron suficientemente abordados, para de tal modo revisar o que se deberá realizar.

Desde estes supostos contéstase a validez dos exames convertidos en definitorios da avaliación e baixo o nome de brevets de especialización, propóñense avaliacións parciais durante os anos da escolaridade cunha lóxica nova que permite contemplar as múltiples capacidades reais: cada alumno pode así ir avaliando o estado dos seus coñecementos ${ }^{55}$.

\section{Metodoloxía de creación documental: o Grupo de Traballo Cooperativo}

O principio da cooperación alimenta o conxunto dos grupos de traballo entre os docentes, que nalgún casos teñen como obxectivo a construción dalgún tipo de recurso ou documentación de alcance didáctico. Hai que indicar que a experiencia de décadas de acción serviu para ir delimitando unha metodoloxía procesual.

Existe no ICEM o chamado Grupo de Traballo Cooperativo, que promove a reunión de persoas/equipos a fin de crear tales recursos ou para asegurar a conexión entre os creadores e a Editora PEMF. A iniciativa de creación dun determinado recurso pode igualmente partir dun determinado membro do ICEM, que informa sobre a súa intención ou necesidade na busca de colaboración ao dito Grupo, ou que incluso ofrece xa ese recurso solicitando unha valoración e a posíbel posta en relación coa Editora.

No caso de darse unha opinión favorábel o recurso creado - logo de ser examinado por un comité de lectura - pasa a ser experimentado en diversas clases que o avalían en situacións didácticas varias e adecuadas para indicar, dado o caso, posíbeis correccións, mediante informes que examinan páxina a páxina as palabras e expresións inadecuadas, que demandan precisións ou que engaden consideracións, facendo igualmente unha valoración de conxunto, que se transmite ao autor. De seguida, pode ser proposto un encontro ou a constitución dun grupo específico de traballo para axudarlle a quen sexa autor na maduración e posta a punto do recurso, podendo entón pasar ao proceso da súa edición.

55 En francés brevet (traducible por "validación" ou "acreditación") ten a súa primeira aparición nun texto de 1947 de C. Freinet, que toma de Baden Powell e do movemento scout. Quere indicar algo así como unha "mostra apreciábel, isto é, valorable, da nova adquisición de aprendizaxe realizada por un alumno como parte dun proceso máis amplo", respondendo a un reto persoal de formación, e tendo a preocupación de que esa mostra teña o trazo e a ambición de ser unha pequena obra mestra e indicio de maduración. 


\section{Freinet/ Montessori: proximidade e diferenzas}

Afírmase con xeral aceptación que se trata de dúas pedagoxías sistémicas e con forte coherencia interna. Rexistramos nas dúas un radical respecto pola natureza infantil, a promoción da expresión e da comunicación infantil e tamén unha radical confianza nas súas capacidades e potencialidades, dado o vitalismo que as informa. As dúas teñen centralmente presente a educación pola acción e o manexo de outils. Con todo, é oportuno indicar que Freinet — que realizou valoracións moi positivas das creacións e da investigación montessoriana-, non deixou de mostrar o seu distanciamento con respecto a aspectos que considerou relevantes; valorou criticamente a educación sensorial e intelectual montessoriana, ao considerala artificiosa e mecánica — unha pedagoxía da exercitación-, ao facela depender Montessori de procedementos e materiais didácticos predispostos con algunha rixidez en nome da ciencia, cun regulado uso en canto a súa progresión, sen que o neno deba comprender o sentido proposto para as distintas actividades e sen que exista un sentido global perceptíbel; salientou igualmente que os procedementos e materiais montessorianos configuran un 'ambiente' proporcionado e libre de obstáculos, que, porén, vén substituír o natural proceso de experiencia infantil e a súa conexión coa vida natural e social. Un ambiente que, por outra parte, pon o acento nas aprendizaxes individuais e nos ritmos de cada neno con descoido da súa socialización.

Actualmente, téndese a apreciar as similitudes e diferenzas que se recollen no seguinte Cadro 1.

Cadro 1. MONTESSORI /FREINET: Similitudes e diferenzas

\begin{tabular}{|l|l|}
\hline MONTESSORI & FREINET \\
\hline $\begin{array}{l}\text { Pedagoxía fundada sobre a posta a punto dunha } \\
\text { contorna e dun material especificamente concibidos } \\
\text { para facilitar as aprendizaxes infantís }\end{array}$ & $\begin{array}{l}\text { Sostén que o material Montessori e as actividades } \\
\text { propostas axéitanse esencialmente as necesidades } \\
\text { infantís ata os 4 anos, mais que logo o neno non se } \\
\text { contenta coa manipulación do material, pois quere } \\
\text { actuar sobre a contorna mediante proxectos, en } \\
\text { situacións de comunicación e de expresión reais }\end{array}$ \\
\hline $\begin{array}{l}\text { O neno ten naturalmente desexo de aprender certas } \\
\text { cousas en certos períodos sensíbeis, variábeis dun } \\
\text { neno a outro, e se estes se respectan non sería precisa } \\
\text { outra motivación. Os éxitos que o neno acumula na } \\
\text { manipulación do material didáctico motívano para } \\
\text { proseguir na súa investigación }\end{array}$ & $\begin{array}{l}\text { O que motiva ao neno é a actuación sobre o mundo } \\
\text { proxectos), responder ás cuestións que se lle } \\
\text { presentan (traballo a partir dos seus intereses e } \\
\text { cuestións) e comunicar con outros (correspondencia, } \\
\text { xornal...) }\end{array}$ \\
\hline $\begin{array}{l}\text { As adquisicións fanse esencialmente manipulando o } \\
\text { material, por medio dun traballo individual guiado } \\
\text { pola educadora }\end{array}$ & $\begin{array}{l}\text { As adquisicións fanse mediante a participación } \\
\text { en proxectos, que inclúen unha comunicación co } \\
\text { exterior }\end{array}$ \\
\hline $\begin{array}{l}\text { O traballo individual sobre o material auto-correctivo } \\
\text { ocupa un lugar central, mentres o traballo colectivo } \\
\text { ocupa un tempo reducido e ten un lugar secundario }\end{array}$ & $\begin{array}{l}\text { A xornada escolar prevé a alternancia de tempos } \\
\text { de traballo individual e do colectivo. O traballo } \\
\text { individual sobre o material auto-correctivo está ao } \\
\text { servizo dos proxectos }\end{array}$ \\
\hline $\begin{array}{l}\text { As actividades incitan pouco aos nenos a } \\
\text { intercambiar entre eles e a cooperar }\end{array}$ & $\begin{array}{l}\text { A cooperación e o traballo en grupo ocupan o lugar } \\
\text { central }\end{array}$ \\
\hline
\end{tabular}




\begin{tabular}{|l|l|}
\hline $\begin{array}{l}\text { O alumnado traballa sobre un material } \\
\text { especificamente concibido para as aprendizaxes }\end{array}$ & $\begin{array}{l}\text { A pedagoxía Freinet considera artificial a ordenación } \\
\text { deste material e propugna a presenza de recursos } \\
\text { realmente utilizados nas actividades diarias. }\end{array}$ \\
\hline $\begin{array}{l}\text { As actividades propostas quedan de ordinario dentro } \\
\text { dos muros da escola (animais, macetas con flores...) }\end{array}$ & $\begin{array}{l}\text { A acción escolar ábrese sobre o exterior mediante } \\
\text { visitas a unha granxa, inquéritos, saídas a } \\
\text { instalacións... }\end{array}$ \\
\hline
\end{tabular}

Fonte: elaboración propia por adaptación de Viaud (2008: 109-111).

\section{Pedagoxía Freinet/ Método Freinet/Técnicas Freinet}

Célestin Freinet non quixo deseñar un "método de autor", cerrado e concluído mediante algunha posterior re-elaboración, como no caso doutras propostas metodolóxicas coetáneas, e por iso nunca falou de Método Freinet, preferindo en troques falar de "Técnicas Freinet", salientando que estas tiñan unha resonancia dinámica ao ligarse á "modernización" dos instrumentos e recursos ${ }^{56}$ que deberían utilizarse na acción educativa segundo a esixíbel modernización de cada momento histórico, aínda que si promoveu a permanencia das técnicas de expresión libre e de comunicación, dada a experiencia contrastada de varias décadas de acción e de reflexión pedagóxica.

Técnicas que chamou da escola moderna, tanto pola pretensión de responder á modernización coa que deberían producirse os procesos escolares de ensino e de aprendizaxe, como por marcar algunha distancia con respecto ao espírito dominante do movemento internacional da Escola Nova, ${ }^{57}$ que en Francia atendía polo acrónimo GFEN, Grupo francés da Escola Nova, do que Freinet chegou a tomar algunha distancia no fin dos anos corenta.

Con todo, nos pasados anos sesenta comezou a falarse de Movemento Freinet e de pedagoxía Freinet (que non de pedagoxía 'de' Freinet), para referirse a unha construción colectiva prácticoteórica, elaborada baixo o liderado ou inspirada na forza intelectual, profesional, ética e política de Élise e de Célestin Freinet. E nestes termos falamos actualmente de pedagoxía Freinet: unha construción pedagóxica colectiva evolutiva —inspirada arredor de Freinet—, que inclúe unha concepción da aprendizaxe escolar, mediante métodos naturais apoiados no tenteo experimental e na expresión, e unha dimensión política e filosófica favorábel á emancipación e transformación escolar e social a través da cooperación, de onde deriva un uso coherente de técnicas pedagóxicas entretecidas por uns valores e principios que lles dan unidade ${ }^{58}$. Deste modo, práctica e teoría

56 Que as institucións educativas incorporen sempre e axilmente os adiantos tecnolóxicos da época que permiten a mellor información e a mellor adaptación a un mundo dinámico e cambiante. Freinet fala de - materialismo pedagóxico - fronte ao verbalismo da escola tradicional: instrumentos, recursos e materiais para a escola en acción. Esta perspectiva — material— está plenamente presente en AA.VV. (1979).

57 Os Freinet tiñan un pé na Escola Nova, aínda que desconfiaban do seu arume burgués, mentres ao tempo se sentían atraídos polos medios libertarios e naturistas e seducidos por algúns aspectos da pedagoxía soviética (Ohayon et al., 2004).

58 "Técnicas integradas nun sistema complexo e coherente cuxo aglutinante está constituído por un principio xeral —o método natural - unha orientación constante - a finalidade emancipadora - e un cadro organizador - a clase cooperativa_-", segundo se indica en Laboratoire de recherche coopérative de l'ICEM (2018: 349). 
interrelaciónanse sen existir un label de pedagoxía Freinet, e si formas diferentes e unificadas a través dun similar conxunto de principios.
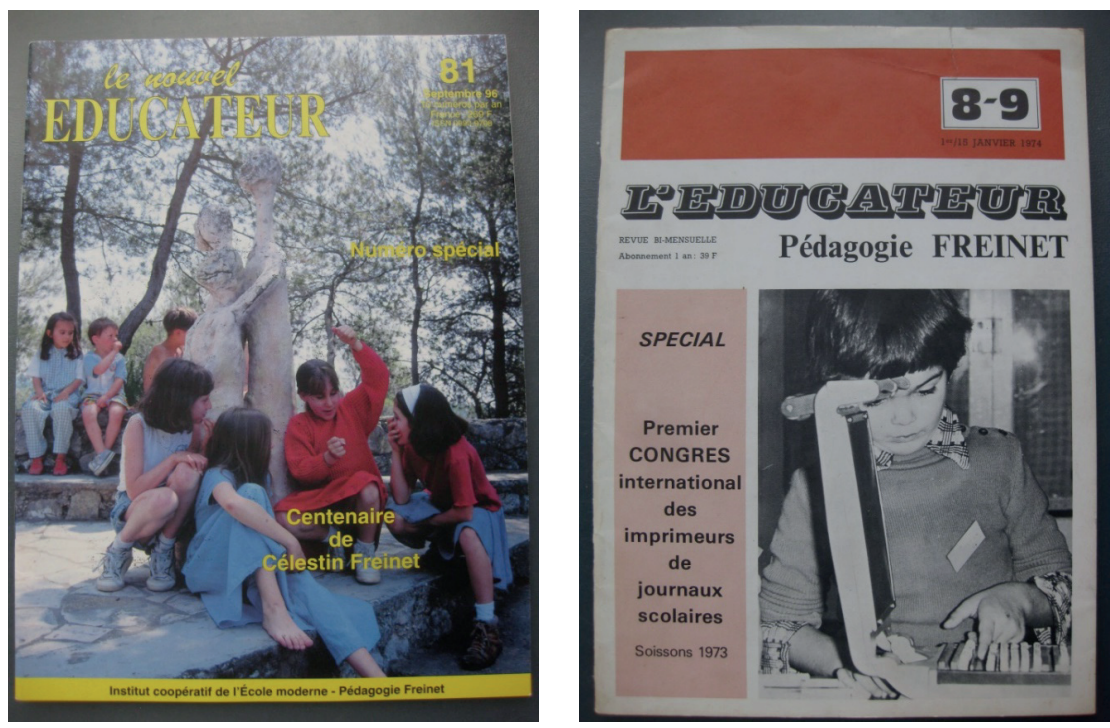

Figura 6. Presentacións da revista do ICEM: en 1996 e 1973. Fonte: arquivo Antón Costa.

\section{Un movemento internacional de educadoras e educadores}

Mediante a constitución dunha rede cooperativa (francesa e internacional) entre ensinantes, Freinet fixo posíbel o intercambio, a comunicación e o debate sobre os acertos e ou dificultades destas prácticas novas, sendo así estes grupos de ensinantes un "intelectual colectivo", como acertou a expresar Henry Peyronie (2006: 11-14, 2015: 39-56) , $^{59}$ en cuxo interior destacaron/ destacan, igualmente, diversas referencias individuais ${ }^{60}$. Os encontros, os traballos das comisións e as reunións organizadas por este intelectual colectivo contribúen a madurar - mediante o principio da cooperación, a posta en común, o estudo e o debate- a conciencia sobre as esixencias e as orientacións dun oficio educador, como o que se propón na Carta da Escola Moderna.

59 Fronte ao protagonismo que Élise Freinet destacou en Naissance d'une pédagogie populaire, Peyronie, sen negar o liderado de Freinet, quere salientar a forza do colectivo francés e internacional de educadores e educadoras freinetianas, ao aplicar a categoría gramsciana do "intelectual colectivo"; isto é, os movementos obreiros progresistas fan emerxer no seu seo as análises que precisan para a súa emancipación, en vez de apropiarse apenas dos instrumentos elaborados por intelectuais próximos. En termos similares expresouse Pierre Bourdieu ao falar do intelectual colectivo como modo de traballo desexábel das forzas de contestación social. Tivo ocasión de volvelo expresar Peyronie en 2015 ao escribir: "une pédagogie imaginée par un fondateur charismatique, mais retravaillée — depuis plusieurs générations - par une sorte d'intellectuel collectif".

60 A título de exemplo, indicamos algunhas referencias: M. Barré, P. Le Bohec, R. Ueberschlag, Mme. Belperron, F. Oury, B. Ciari, Tamagnini, F. Tonucci, M. Lodi, A. Pettini ou Jean Le Gal. 
Foi así como se creou en 1957 a Federación Internacional de Movementos de Escola Moderna (FIMEM) para reunir diversas organizacións nacionais, con seus periódicos Rencontres Internationales des Éducateurs Freinet (RIDEF), ao tempo que o ICEM francés mantén unha coordinación con outras plataformas e organizacións como o GFEN e os Grupos CEMEA, mediante o CLIMOPE creado en $1985^{61}$.

\section{Orixinalidade e actualidade da pedagoxía Freinet}

Freinet, en question?: isto era o que preguntaba o $\mathrm{n}^{\circ} 155$ (1977) de Cahiers Pedagogiques. Pouco despois (1980:387) Louis Legrand afirmaba o valor desta pedagoxía e a profunda interconexión nela entre "o camino da razón e o do corazón". Entre nós así o consideran tamén Francesc Imbernon (1996: 30), Jaume Carbonell (1996: 31), que se referiu ao magnetismo freinetiano e Josep Alcobé (1996: 32), quen foi a ponte entre o tempo da II República e as décadas finais do século XX, ao falar da pedagoxía Freinet como dunha "pedagoxía para o futuro".

É frecuente incluír as técnicas Freinet ao falar de "pedagoxías activas" como se se tratara dun pool onde escoller innovacións educativas, dado que o mesmo Freinet non fora 'orixinal' á hora de valerse de distintas técnicas didácticas que outros avanzaran, como el mesmo salientou (1959:4):

Somos continuadores de Decroly, à qui nous debons tout. Perfeccionamos e completamos as técnicas que el descubriu, e á vez que aproveitamos as indagacións técnicas de Cousinet sobre o traballo en grupos e de Profit sobre a cooperación escolar. Aínda que, quizais sexa Ferrière quen, cos seus libros $L$ 'École active e La pratique de l'École Active ${ }^{62}$ foi quen, entre os pedagogos contemporáneos, mellor soubo unir teoría e práctica, sen descoidar nin a unha nin a outra. Ferrière foi autor de valiosos textos cos que difundiu as orientacións da Escola Nova e Activa. Seguín igualmente con moito proveito as experiencias das escolas novas desenvolvidas entre as dúas guerras (1918-1939, noso), na École du Mail de Xenebra por Dottrens, en América co plan Dalton en Washburn, en Hamburgo e na URSS...As nosas técnicas... son como o froito no plano técnico dos esforzos xenerosos de todos os educadores a quen eu quero render aquí unha homenaxe indiscutíbel e definitiva. En todo caso, desexamos que outros, logo de nós, poidan utilizar de igual modo a nosa achega a fin de ir aínda máis lonxe polo excelso ben da nosa escola popular.

Porén, a pedagoxía Freinet ten a súa singularidade na súa coherencia interna arredor dun proxecto político crítico, laico, democrático e emancipador e está atravesada por principios éticos e filosóficos que son os seus fundamentos (Laboratoire, 2018: 13). Unha coherencia que se fai visíbel no seu horizonte social e humano transformador - como se sinala na Carta da Escola Moderna-; na importancia do grupo de iguais nos procesos de construción cooperativa da liberdade, da autonomía e da responsabilidade; nos procesos de apropiación dos saberes mediante métodos naturais de aprendizaxe de diferentes linguaxes e o desenvolvemento da creatividade, e na posta en práctica de

${ }_{61}$ Comité de Liaison entre les Mouvements Pédagogiques et d'Éducation.

62 Os textos aludidos foron traducidos ao castelán como La práctica de la escuela activa e La escuela activa. (Madrid: Francisco Beltrán, 1928 e 1932, respectivamente). 
instrumentos e técnicas que respectan os aspectos indicados e que favorecen o tenteo experimental, a valorización das intelixencias múltiples, a comunicación e a apertura ao mundo.

É, ademais, unha obra colectiva e orixinal: a dun grupo/s cooperativo/s de prácticos-teóricos, que elaboran con atención instrumentos e técnicas ao longo do tempo. Neste sentido, Giauque et Tieche (2015:18) consideran que a pedagoxía Freinet permanece actual, entre outros motivos, porque Freinet máis alá do empirismo das prácticas fundou a lexitimidade da súa pedagoxía sobre o exame detallado e documentado das conexións entre a práctica e os seus efectos.

Pola súa parte, Peyronie (2015:19) considera que as técnicas e propostas da pedagoxía Freinet constitúen un corpus aberto e susceptíbel de evolucionar baixo o impulso da rede cooperativa que no presente continua a renovarse, algo que igualmente salientan Boumard (1996: 53) ao indicar: "Freinet soubo impulsar un movemento de pedagogos militantes mediante a creación dunha rede de educadores que poñen en común as súas prácticas, as súas reflexións e a súa esperanza nas persoas", e Aldo Pettini (1977: 132) que salientou o papel de Freinet: "unir os esforzos, colaborar, aproximar as persoas mediante o traballo en común, efectuado con vistas a unha progresiva liberación e elevación da humanidade" 63 .

En efecto, a cooperación é unha dimensión moi presente desde o inicio, como recolle Élise Freinet ao referirse (1975: 52) a unha carta circular de Freinet dirixida en 1926 ao grupo de primeiros impresores:

Para a experimentación dunha técnica nos seus inicios é absolutamente indispensábel unha colaboración constante de todos. Poñemos en común as nosas observacións, as nosas descubertas, os nosos deberes e tamén os nosos erros, para axudarnos mutuamente. Pídovos que me escribades extensamente, para pedir ou para dar algunha información. Eu farei todo o que poida para que cada un de vós se aproveite destas correspondencias.

\section{Estamos ante unha adecuada elaboración?}

Algúns investigadores adoptaron unha posición crítica a este respecto, ao referir certo eclecticismo nos textos de Freinet ou ao sinalar que o seu pensamento escrito ten algo de desordenado. Así, Aida Vásquez e F. Oury (1967: 200) indicaron que en ocasións aos seus textos fáltalles claridade e rigor ao entrelazarse e superpoñerse, como na acción diaria do educador, técnicas, principios, filosofía da infancia, hipóteses psicolóxicas, xuízos de valor ou opinións moi persoais, sendo un exemplo disto o modo como utiliza frecuentemente a palabra "natural", que é unha palabra ambigua, como salientou Jean Vial (1989: 11).

González Monteagudo, pola súa parte, ao tempo que anota a súa amplitude temática e expositiva, parece apreciar (2009: 77) con algunha frecuencia, unha escritura imprecisa, ambigua, metafórica, parabólica e poética, que dificultaría o seu contraste académico, recoñecendo, con todo,

63 Aldo Pettini, con Tamagnini, foi introdutor da pedagoxía Freinet en Italia, a partir do seu texto de $1950 \mathrm{Le}$ tecniche Freinet (Rimini: ODCU), centrado na explicación da tipografía, a correspondencia e os plans de traballo, co coñecemento infantil como base, tendo por horizonte a satisfacción e educación das necesidades infantís e como medio as diversas técnicas. 
que é a escrita militante de quen está intimamente ligado á acción educativa, desde a que reflexiona e realiza indicacións, mesturándoas con parábolas e exemplos que se refiren ao mundo biolóxico e natural circundante. Unha escrita co risco do empirismo e do anti-teoricismo e con nesgo naturalista, que confía no saber do sentido común ao derivarse da experiencia, aínda que, ao mesmo tempo — sostén Monteagudo - Freinet sabe extraer dese risco a súa orixinalidade, potencia retórica e capacidade de atracción.

Pola súa parte Bruliard (1998: 45) chamou a atención sobre que as nocións de "tenteo experimental" e de "método natural" acomódanse mal aos criterios usuais de cientificidade; algúns investigadores puxeron de manifesto que as referencias de Freinet ao pensamento natural, á permeabilidade a experiencia e a súa concepción sensualista do coñecemento teñen algunhas limitacións. Así, Vergnioux (1998: 68) chamou a atención sobre que a perspectiva vitalista da aprendizaxe en Freinet, que sostén unha idea de continuidade 'natural' entre as primeiras experiencias infantís e as formas máis elaboradas de coñecemento, é contraditoria coa perspectiva bachelardiana, que pon mais insistencia nas mediacións e nas rupturas, así como no erros iniciais e ser superados para unha mellor aprendizaxe. Alain Guy, pola súa parte, expresou algunhas reservas arredor da psicoloxía sensitiva de Freinet, por conducir a unha especie de 'pedagoxía natural' (Guy, 1997: 68), cando con Bachelard sabemos que a ciencia rompe co ‘sentido común'(en Fabre, 1998: 53).

Con todo, hai reflexións de Freinet nesta cuestión que se encontran revalidadas polos estudos actuais sobre o pensamento natural (Jardine, 1989: 203-213). Así por exemplo, ante a consideración dos estadios de desenvolvemento piagetiano Freinet — coñecedor das observacións de Piaget sobre a evolución infantil — recomendaba non precipitar os movementos internos naturais do neno, poñendo a maior atención en darlle aos nenos diversidade de medios de acceder ao coñecemento.

Tamén a elaboración freinetiana sobre a "experiencia tenteada" ten suscitado debates de certa relevancia: é unha teoría que ten conexións co paradigma ensaio-erro, o que lle permite romper co intelectualismo, ao tempo que Freinet evitou as posicións mecanicistas e a artificialidade das condutas (que se derivan do condutismo de Watson) ${ }^{64}$, mais, debido a esta súa dependencia do condutismo - que prescindiu das representacións, das crenzas e das concepcións dos individuos (ao considerar só as condutas observábeis) — o "tenteo experimental" freinetiano non se presentaba como adecuada vía de aprendizaxe, segundo André Giordan (Fabre, 1998: 49-50), ao non interrogarse polo erros de xuízo, de ideas e de representacións: para Freinet o obstáculo está "sempre diante do alumno", e non "no interior" como sinalara Bachelard, debido a unha concepción errónea.

Asumida esta deficiencia, o discurso actual da pedagoxía Freinet corrixiu estes puntos iniciais e toma en consideración a vertente psicolóxica da aprendizaxe: integra tanto a perspectiva do "erro inicial" como a importancia da interacción social, como elementos indisociábeis do tenteo experimental, en concordancia cos traballos de Bachelard, Piaget e Jean-Pierre Astolfi (1997), na liña do modelo construtivista, segundo o que aprender é franquear paulatinamente unha serie de obstáculos en función de coñecementos máis elaborados (Laboratoire..., 2018: 159).

64 Freinet distánciase do condutismo por preferir unha motivación 'natural' como lei fundamental da aprendizaxe por ensaio-erro, en lugar dos reforzos positivos ou negativos exteriores, achegándose, deste modo, á inspiración bergsoniana. 
Yves Reuter (2008), pola súa parte, puxo de manifesto os efectos socialmente reparadores da pedagoxía Freinet. Saliéntanse, ademais, outros aspectos moi positivos da pedagoxía Freinet, entre eles, as súas referencias ás conexións afectivo-cognitivas — isto é, provocar o desexo de aprenderás que vén referíndose a investigación no campo das neurociencias: como indica Francisco Mora (2013) “só pode ser verdadeiramente aprendido aquilo que nos chama a atención e nos xera emoción". Fíxose notar igualmente que hai posicións e prácticas freinetianas revalidadas polas elaboracións psicolóxicas de Vigotski, de Bruner e de Gardner.

Diversas indagacións recentes reafirman a orixinalidade e actualidade da pedagoxía Freinet — como indicou Avanzini (1987: 23) — por ter sabido innovar na aplicación nova de recursos e conceptos previamente recoñecidos, destacando a permeabilidade das súas técnicas e a súa intelixencia de práctico-teórico, a súa capacidade para xerar proxectos de investigación-acción, o seu liderado militante, a súa capacidade como federador de vontades de transformación escolar, a súa riqueza de didactismo expresivo e a súa paixón e amor polos nenos, singularmente por aqueles mancados por algunha infelicidade, sendo evidentes os enfoques e prácticas que actualmente se lle deben.

Sen ser plenamente conscientes, hai profesores/as que aplican unha orientación pedagóxica coincidente coa pedagoxía Freinet, cando poñen aos nenos no centro da pedagoxía, entre a individualización e a socialización; cando os alumnos interveñen na xestión da clase, tomando decisións no día a día e a través da asemblea, como modo de educación práctica, e realizan a súa acción educadora cun horizonte de transformación de prácticas educativas e sociais, ou cando coa súa conduta profesional se implican na xestión democrática da escola, como parte da xestión democrática e progresista da sociedade.

De modo que, como indica F. Imbernon (2010: 125):

Estudar e aplicar o pensamento de Freinet significa efectuar unha descuberta continua, porque son moitos e moi ricos os estímulos que nos formula. Por medio da organización cooperativa, máis importante aínda que as mesmas técnicas, Freinet continua sendo un grande educador de educadores.

\section{A PEDAGOXÍA FREINET NO ESTADO ESPAÑOL E EN GALICIA}

Esta orientación pedagóxica atopou en Cataluña unha pronta audiencia, que axiña se estendeu por outros lugares da xeografía española. Estamos a falar dos primeiros anos 30 do século $\mathrm{XX}^{65}$.

Por medio de distintas publicacións como a Revista de Pedagogía, coas súas series editoriais de difusión pedagóxica, o Boletín de la Institución Libre de Enseñanza ou de La Escuela Moderna, e mediante o impulso da Junta de Ampliación de Estudios (JAE), coas súas bolsas para o envío de

65 Dispoñemos de diversos traballos académicos que reconstrúen con finura o que foron os antecedentes e o desenvolvemento da pedagoxía Freinet en España ao longo dos anos vinte e trinta do pasado século XX: os estudos de Fernando Jiménez-Mier (1996, 2007, en particular), Sampedro Garrido (1999), Costa Rico (2010), Hernández Díaz e Hernández Huerta (2011 e anteriores), Ramos (2015) e Hernández Huerta (2017), entre outros. 
profesorado ao países europeos para a súa formación, o coñecemento das innovacións pedagóxicas internacionais e de modos novos de realización escolar comezaba a ser palpábel na realidade social española andando os anos vinte. Así, comezou a saberse tamén de Freinet. Naquel tempo chegou a haber dous Congresos da Imprenta na Escola celebrados en Cataluña, en 1934 e 1935, baixo a organización da Cooperativa Española de la Técnica Freinet, editora desde 1935 da revista Colaboración.

Un papel relevante na súa difusión correspondeulle ao inspector de educación albaceteño Herminio Almendros, que chegou a ser amigo persoal dos Freinet e autor en 1932 do libro $\mathrm{La}$ imprenta en la escuela. La técnica Freinet. Con ela podía levarse a cabo un novo modo de educación escolar, como escribiu Freinet (in Almendros, 1932: 369-370):

(...) utilizamos a imprenta na nosa escola co propósito de liberar a mestres e alumnos da tiranía dos textos mortos (...). A imprenta dá aos nenos un método de cooperación mundial e de intercambio de ideas; fai da escola parte da vida que xorde do mundo. (...) A linguaxe benefíciase pola reiterada e coidada composición feita cun propósito claramente comprendido; (...) dá un novo sentido ao ensino da gramática; (...) afina o poder de observación e de experimentación individual e de grupo; vigoriza directamente o traballo científico (...). Os cambios interescolares prestan tamén á ciencia da natureza un interese moi vital. A aritmética forma unha parte integrante da vida dos nenos. No que se refire á historia, o noso Livre de vie (...) dá aos nenos unha primeira visión do sentido histórico (...). A xeografía chegou a ser tamén (...) un estudo racional e vivo. En compañía con outros novos camaradas de Francia e doutras partes do mundo, coñecen outras provincias e países, os seus climas, produtos, camiños e costumes, vistos cos ollos das crianzas (...) Abolimos o ensino hipócrita da moralidade e no seu lugar, os esforzos cooperativos axúdannos a conseguir unha boa conduta ${ }^{66}$.

En Galicia houbo daquela varios ensinantes atraídos polas prácticas pedagóxicas de Freinet. De quen máis sabemos é do mestre de A Cañiza José Benito González, quen cos seus alumnos da escola pública tiraba do prelo o xornal El Faro Infantil (Costa Rico, 1996a: 24-25, e 2012: 5778) ${ }^{67}$; tamén podemos falar de El pequeño escolar elaborado en Reinante (Lugo) e de Floración feito en Pontedeume por impulso do mestre Frutos Fernández (Costa Rico, 2019); mesmo hai unha referencia a unha escola galega en $L^{\prime}$ Éducateur Proletarien en 1933 (Cuscoy, 1933: 427-430) ${ }^{68}$.

Logo viñeron a guerra e a ditadura, impedindo unha maior extensión e un suco máis profundo do que se iniciaba. Algúns educadores levaron a pedagoxía Freinet a América: a Arxentina, a Cuba e singularmente a México, onde se consolidou o grupo de exiliados máis numeroso, como estudou

66 Texto de C. Freinet publicado en inglés en The New Era e recollido en castelán por Herminio Almendros.

${ }_{67}$ Logo das nosas achegas publicouse un coidado estudo monográfico sobre José B. González elaborado por Porto Ucha e Vázquez (2017).

68 O mestre Diego Cuscoy, catalán, ocupou un posto interino na escola da parroquia Castro das Seixas (Palas de Rei), e informa sobre o modo de traballo da lectura na escola. O texto escrito e publicado na Revista de Pedagogía, dirixida por Luzuriaga, foi logo traducido ao francés e enviado a Freinet que o publicou. Pronto este profesor pasaría a Tenerife onde continuou accións pedagóxicas similares. 
Fernando Jiménez; na Arxentina o mestre Luis Fortunato Iglesias, fillo de nai e pai galegos veu sendo tamén un destacado educador freinetiano (Costa Rico, 1996b: 38-42, 2016a: 305-321). Porén, tivemos que agardar aos pasados anos sesenta para que de novo algúns pequenos grupos de ensinantes de Valencia, de Cataluña e de Santander comezaran a se sentir influenciados pola pedagoxía Freinet. Ferrán Zurriaga nas páxinas da revista Triunfo -pan de demócratas en tempos de fame de democracia- informábanos ao respecto no ano 1971, no mesmo ano no que aparecían editados en español os escritos de Freinet agrupados baixo o título Parábolas para unha pedagoxía popular (Os ditos de Mateo), abrindo o camiño ás sucesivas edicións de textos desde as editoriais barcelonesas Avance e Laia, en particular. Abría o tempo da formación de pequenos grupos de ensinantes, cos que en maio de 1974 se constituíu a Asociación para a Correspondencia e a Imprenta Escolar $^{69}$, que cambiou a súa denominación no 1978 pola de Movemento Cooperativo de Escola Popular (MCEP), co que hoxe o coñecemos ${ }^{70}$.

Nos anos setenta, cando un alto número de mozos e mozas se incorporaban á docencia como profesores noveis e cando a apelación galeguizadora cobraba enerxía, a recepción entre nós dos textos escritos de Célestin e de Élise Freinet publicados en castelán foi pan fresco: a forte impregnación rural da nosa identidade cultural e lingüística e o carácter sociolóxico dos estímulos renovadores sentidos daquela en Galicia fraguaban ben coa biografía loitadora, impregnada de cultura rural e educadora de Freinet e co didactismo, riqueza e calidade dos seus escritos. Viña, así, a formar e consolidar conciencias profesionais e militantes pola educación popular e democrática.

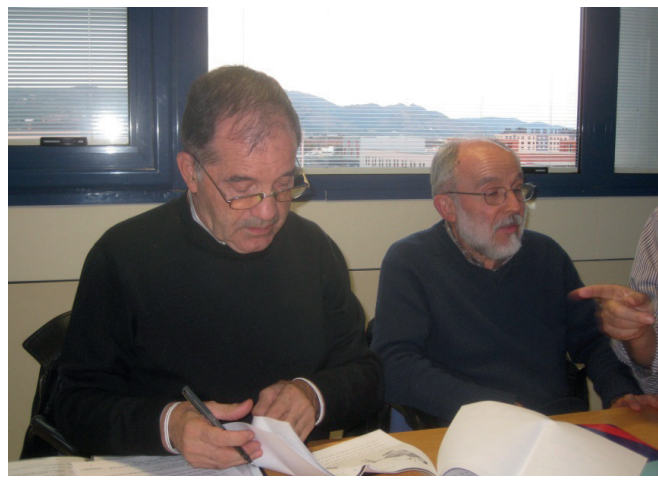

Figura 7. Ferrán Zurriaga, iniciador da pedagoxía Freinet en Valencia nos pasados anos sesenta, e Fernando Jiménez, investigador da presenza de educadores españois freinetianos en México, nun encontro de traballo en 2012. Arquivo: Antón Costa.

69 Nesta constitución participamos a profesora Carmen Fernández García, daquela na Escola de Maxisterio de Lugo, Ana María Pardo Múgica, psicóloga escolar no colexio Fingoi de Lugo e Antón Costa, estudante de pedagoxía na Universidade Pontificia de Salamanca.

70 É do caso salientar que Ferrán Zurriaga vén impulsando un Seminario de estudo histórico do movemento Freinet en España, en colaboración coa Fundació Cátedra Soler i Godes da Universitat Jaume I de Alacant. Esta Cátedra e a Biblioteca conforman o máis completo arquivo documental sobre a historia da pedagoxía Freinet en España, en conxunción coa Biblioteca de Rosa Sensat en Barcelona, o Arquivo do Departament d'Educació do Ajuntament de Barcelona e o Arquivo da Biblioteca Pública de Albacete, que atesoura os fondos documentais de Herminio Almendros. 
En setembro de 1973 dous mestres procedentes de Murcia impartirían un seminario de técnicas Freinet para un grupo de mestras da Baixa Limia, arredor da profesora Maribel Santos, como experiencia primeira e limitada a aquel espazo. Mais, foi en setembro de 1975 cando se rexistrou o acto fundacional do grupo galego, a través de diversos pequenos encontros celebrados en Santiago ${ }^{71}$, A Coruña, Ourense, Lugo e Pontevedra. Na fin do curso 1975-76 había ensinantes ligados a esta orientación en diversas localidades de Galicia, estendéndose tamén a Vigo, Ferrol, O Salnés, e a Bergantiños. Acompañan a este movemento prácticas pedagóxicas renovadoras nas escolas do país: a práctica do texto libre e a correspondencia escolar, estendidas mediante o sistema de impresión e duplicación da xelatina e as multicopistas, os xornais escolares coa vida relatada polos nenos en galego, os estudos do medio, a valoración da arte e a expresión libre infantil, as asembleas de aula, os planos de traballo de aula... e a loita pola democracia educativa e política ${ }^{72}$.

Naqueles últimos anos setenta impúlsanse varios encontros e intercambios de experiencias por parte do conxunto do colectivo, o Movemento Cooperativo de Escola Popular Galega (MCEPG). Sentíase a necesidade dunha publicación periódica: en 1978 comezaba co $\mathrm{n}^{\circ} 0$ a edición da primeira revista pedagóxica en lingua galega, As Roladas $-2^{73}$ que terminou sendo coñecida como As Roladas por parte de varios centos de subscritores; contra vento e marea aguantou ata o ano 1981: dez exemplares e un suplemento.

Un tempo de iniciativas, no que se celebran Xornadas do Ensino, que desde final dos setenta convocou con continuidade a Asociación Socio-Pedagóxica Galega (ASPG), e diversas Escolas de Verán, estando en todas elas presentes estas innovacións didácticas, que será tamén un tempo de parciais fracasos e de contrariedades organizativas, nun contexto de angostura política (co inicio dunha Autonomía de Galicia controlada polos conservadores e a dereita política), que afectou ao MCEP de Galicia: os anos 1981-83 foron de deserto do que era mester saír.

En abril de 1983 unha reunión de 17 ensinantes, membros representantes de varios reducidos colectivos pedagóxicos, entre eles o MCEPG, valoraba a posibilidade de abrir un tempo novo para a renovación pedagóxica organizada (Costa Rico, 1996c: 33-37). E así, o 11 de xuño de 1983 en presenza de 145 mulleres e homes de todo o país, nacía Nova Escola Galega, que englobaría no seu seo a diversos colectivos pedagóxicos, tamén o MCEPG. Todos serían en diante parte da casa Nova Escola Galega, aprendendo das orientacións e das intelixencias e prácticas pedagóxicas que se achegaban, todas formuladas desde a concepción dunha educación pública, democrática, laica e galega. O noso presente ten, así, raíces na educación popular propugnada pola Pedagoxía Freinet.

71 En xuño de 1975, convocado polo profesor José Pérez Vilariño, impartín en Santiago un breve seminario sobre a pedagoxía Freinet nun curso de formación do profesorado por el coordinado no Instituto de Ciencias da Educación. O meu ofrecemento para prolongar este seminario con diversas sesións durante o curso 197576 serviría a esta finalidade, igual que as sesións celebradas en Lugo, A Coruña e en Ourense naquel curso, momento no que o profesor Antonio Espinosa González en Pontevedra e as profesoras Mercedes Suárez Pazos en Ourense, Carmen Fernández en Lugo e Sabela Díaz Regueiro en Ferrol, igualmente propiciaron a creación de grupos comarcais.

72 Entre os e as ensinantes que se ían incorporando hai que anotar a Avelino Pousa Antelo, o fío máis evidente de conexión en Galicia no campo escolar primario co tempo final da II República.

73 As Roladas fora unha breve iniciativa de 1922, escrita en galego, que quería ir dirixida á infancia en Galicia. 
Sen dúbida, a orientación da pedagoxía Freinet é unha das máis dinámicas expresións internacionais do desenvolvemento do pensamento e da prácticas pedagóxica actualmente. Un laboratorio socio-educativo a ter presente e a tomar en consideración nos debates de educación que suscita o tempo actual de tan intensos cambios socio-culturais

\section{Para seguir na rede o presente do Movemento Freinet}

https://asso-amis-de-freinet.org

https://www.fimem-freinet.org/pt-pt/node/3319

http://www.ecolebizu.org/moulle

\section{BIBLIOGRAFÍA}

\section{Ler a Célestin Freinet}

Los métodos naturales III: El aprendizaje de la escritura, Barcelona: Fontanella/Laia, 1972.

Los métodos naturales I: El aprendizaje de la lengua, Barcelona: Fontanella, 1979.

Los métodos naturales II: El aprendizaje del dibujo, Barcelona: Fontanella, 1979.

La psicología sensitiva y la educación, Buenos Aires: Troquel, 1969.

Parábolas para una pedagogía popular, Barcelona: Estela, 1970.

La educación por el trabajo, México: FCE, 1971.

Modernizar la escuela, Barcelona: Laia, 1972.

La formación de la infancia y de la juventud, Barcelona: Laia, 1972.

La educación moral y cívica, Barcelona: Laia, 1972.

Por una escuela del pueblo, Barcelona: Laia, 1973

El texto libre, Barcelona: Laia, 1973.

La enseñanza del cálculo, Barcelona: Laia, 1973.

La enseñanza de las ciencias, Barcelona: Laia, 1973.

Los planes de trabajo, Barcelona: Laia, 1973.

La lectura en la escuela por medio de la imprenta, Barcelona: Laia, 1973.

Consejos a los maestros jóvenes, Barcelona: Laia, 1974.

El diario escolar, Barcelona: Laia, 1974

El método natural de lectura, Barcelona: Laia, 1974.

Las técnicas audiovisuales, Barcelona: Laia, 1979.

Las enfermedades escolares, Barcelona: Laia, 1982.

Las invariantes pedagógicas, Barcelona: Laia, 1982.

La salud mental de los niños, Barcelona: Laia, 1982.

As técnicas Freinet da escola moderna, Pontevedra: Kalandraka, 2019.

\section{Élise Freinet}

L'enfant artiste, Cannes: Imprimerie Robaydy, 1963

La santé de l'enfant, Gap: Editions Ophrys, 1946.

¿Cuál es el papel del maestro?¿Cuál es el papel del niño?, Barcelona: Laia, 1972. 
Dibujos y pinturas de niños, Barcelona: Laia, 1972.

Nacimiento de una pedagogía popular, Barcelona: Laia, 1975

La escuela Freinet. Los niños en un medio natural, Barcelona: Laia, 1981.

La trayectoria de Célestin Freinet: la libre expresión en la pedagogía Freinet, Barcelona: Gedisa, 1978.

Pedagogía Freinet. Los equipos pedagógicos como método. Teoría y técnicas, México: Trillas, 2011.

\section{REFERENCIAS BIBLIOGRÁFICAS}

AAVV (1979). La pedagogía Freinet por quienes la practican. Barcelona: Laia.

Alcobé, J. (1996). O tenteo experimental. Revista Galega de Educación, (26), 14.

Almendros, H. (1932). La imprenta en la escuela. Revista de Pedagogía, (128).

Almendros, H. (1932). La imprenta en la escuela. La técnica Freinet. Madrid: Publicaciones de la Revista de Pedagogía.

Avanzini, G. (1987). L'originalité de Freinet. L'Éducateur. Documents, 190-191.

Barré, M. (1996). C. Freinet, un éducateur pour notre temps: T.I: 1896-1936. Les années fondatrices; T.11: 1936-1966. Mouans-Sartoux: Publications de L'École Moderne Française (PEMF).

Bertheloot, C. e Barré, M. (1980). Aspectos terapéuticos de la Pedagogía Freinet. Barcelona: Laia.

Boumard, P. (1996). Célestin Freinet. Paris: PUF.

Bruliard, L. (1998). Un exemple de l'émergence des sciences humaines dans le mouvement Freinet. Le conflicte avec 1'Institut Parisien de 1'École Moderne (1958-1961). En H. Peyronie, Freinet, 70 ans après. Caen: Université de Caen.

Bruliard, L. e Schleminger, G. (1996). Le Mouvement Freinet: des origines aux années quatre-vingt. París: L'Harmattan.

Carbonell, J. (1996). O magnetismo freinetiano. Revista Galega de Educación, (26), 31.

Cavinato, G. (1998). Primer contacto con la lengua escrita: continuidad con la experiencia espontánea del niño. Kikiriki. Cooperación Educativa (Monográfico "Leer y escribir en la escuela"), (48), 27-35.

Chabrun, C. (2016). Le maître insurgé. Écrits (1920-1939). Paris: Libertalia.

Clanché, P. e Testanière, J. (Dirs.) (1989). Actualité de la Pédagogie Freinet. Bourdeaux: Presses Universitaires de Bourdeaux.

Clanché, P. (2009). Anthropologie de l'écriture et pédagogie Freinet. Caen: Presses Universitaires de Caen. DOI: https://doi.org/10.4000/books.puc.7312

Clanché, P., Debarbieux, E. e Testaniere, J. (Dir.) (1994). La pédagogie Freinet, mises à jour et perspectives. Bordeaux: Presse Universitaires de Bordeaux.

Costa Rico, A. (1996a). José B. González, un mestre galego nos anos 30. Revista Galega de Educación, (26), 24-25.

Costa Rico, A. (1996b). Luís Iglesias: un mestre freinetiano galego-arxentino. Revista Galega de Educación, (26), 38-43.

Costa Rico, A. (1996c). O movemento cooperativo da Escola Popular Galega (1975-1983). Revista Galega de Educación, (26), 33-37. 
Costa Rico, A. (1997). Célestin Freinet: un educador, unha pedagoxía, en C. Freinet, Técnicas Freinet da Escola Moderna (pp. 7-23). Vigo: Edicións Xerais de Galicia.

Costa Rico, A. (2010). D'abord les enfants. La Pedagogía Freinet en España (1926-1975). Santiago de Compostela: Servizo de Publicacións da USC.

Costa Rico, A. (2011a). ¿Qué hay más precioso que el porvenir de un niño? Comentarios y anotaciones alrededor de la Pedagogía Freinet. En Letra a Letra (ed. facsimilar) (pp. 9-30). Huesca: Museo Pedagógico de Aragón.

Costa Rico, A. (2011b). Célestin e Élise Freinet y su influencia entre el profesorado español (19261975). En A. Costa Rico e M. M. Louro Felgueiras (Eds.), Exilios e viagens. Idearios de liberdade e discursos educativos Portugal- Espanha, sec. XVIII-XX (pp. 193-216). Porto: Sociedade Portuguesa de Cièncias da Educaçâo.

Costa Rico, A. (2012). La Pedagogía Freinet en Galicia (1931-1978). En F. Zurriaga (Coord.), Págines vives. Quaderns Freinet. Les revistes escolars de la Segona República (pp. 57-78). Castelló: Fundació Soler i Godes/Publicacións de la Universitat Jaume I.

Costa Rico, A. (2016a). Luis F. Iglesias (1915-2010), Pedagogo latinoamericano, Galicia e Nova Escola Galega, con Jesualdo ao fondo. Innovación Educativa, (26), 305-321. DOI: https:// dx.doi.org/10.15304/ie.26.3678

Costa Rico, A. (2016b). Textos libres, periódicos y correspondencia escolar freinetiana: redes que derriban fronteras. En L. E. Galvan Lafarga, et alii (Coords.), Más allá del texto: autores, redes del saber y formación de lectores (pp. 201-216). México: Centro de Investigaciones y Estudios Superiores en Antropología Social/ Publicaciones de la Casa Chata.

Costa Rico, A. (2019). O mestre Frutos Fernández Martínez e o mutualismo escolar. Unha páxina da historia da educación social en Galicia. Cátedra. Revista de Estudios Eumeses, (26), 1-12.

Cuscoy, D. L. (1933). L'amour a la lecture. Un essai de lecture conscient dans une école rural. L'Éducateur Prolétarien, Maio.

Delobbe. G. (2019). Avec Freinet: l'inversion du champ pédagogique. Mayenne: Editions les Amis de Freinet.

Dewey, E. y J. (1918). Escuelas de mañana. Madrid: Hernando (Tradución de L. Luzuriaga de Schools of Tomorrow, 1915).

Dubreuck, E. (2017). Un cour d'enfant? Enquête généalogique sur l'expérience de l'enfant. T.I: S'émanciper et s'épanouir. T. II: Socialiser et libérer. Paris: L'Harmattan.

Fabre, M. (1998). Freinet et les didactiques. En H. Peyronie (dir.), Freinet, 70 ans après: une pédagogie du travail et de la dédicace. Caen: Université de Caen.

Ferrière, A. (1921). L'autonomie des écoliers. L'art de former des citoyens pour la nation et pour l'humanité. Neuchâtel: Delachaux \& Niestlé.

Freinet, C. (1959). Fondements psychologiques, philosophiques, psychiques et sociaux des Techniques Freinet. Techniques de Vie, $\mathrm{n}^{\mathrm{o}} 1$.

Freinet, C. (1960). Le texte libre. Cannes: PEMF.

Freinet, C. (1964). Bandes enseignantes et programmation. Cannes: Bibliothèque de l'École Moderne.

Freinet, C. e M. Bertheloot (1966). Travail individualisé et programmation. Cannes: Bibliothèque de l'École Moderne. 
Freinet, C. (2019). As técnicas Freinet da Escola Moderna. Pontevedra: Kalandraka (Colección "Biblioteca de Pedagoxía").

Freinet, E. (1974). Prologue. En G. Piaton, La pensée pédagogique de Célestin Freinet. Toulouse: Privat.

Freinet, E. (1975). Nacimiento de una pedagogía popular. Barcelona: Laia.

Freinet, E. (1977). L'itinéraire de Célestin Freinet. La livre expression dans la Pédagogie Freinet. París: Payot.

Freinet, E. (1981). La escuela Freinet. Los niños en un medio natural. Barcelona: Laia.

Fuentes Codera, M. (2017). Freinet abans Freinet: el rebuij de la guerra i la perspectiva revolucionária. História i Educació, (29), 17-40.

Giauque, N. e Christianat, Ch. (Dirs.) (2015). La Pédagogie Freinet. Concepts, valeurs, pratiques de clase. Lyon: Chronique Sociale.

Go, H. L. (2007). Freinet à Vence. Vers une reconstruction de la forme scolaire, Rennes: Presses Universitaires de Rennes.

Go, H. L. (2018). Itinéraire de construction d'une pensée pédagogique. En X. Riondet, R. Hofstetter e H. L. Go (dirs.), Les acteurs de l'Education nouvelle au XXe. Siècle (pp. 45-62). Grenoble: Presses Universitaires de Grenoble.

González Monteagudo, J. (1988). La pedagogía de Célestin Freinet. Contexto, bases teóricas, influencia. Madrid: CIDE-MEC.

González Monteagudo, J. (2009). La escritura pedagógica de Célestin Freinet. Entre retórica literaria y educación renovadora. En A. Zambrano (Ed.), Littérature et formation. Cali (Colombia): Universidad Santiago de Cali.

Guy, A. (1997). Lecture clinique d'un Essai de Psychologie sensible. En A. Lamihi (dir.), Freinet et l'École Moderne. Vauchrétien: Ivan Dary.

Hernández Díaz, J. M. e Hernández Huerta, J. L. (2011). La influencia de Celéstin Freinet en España durante la década de 1939. Estado de la cuestión. En J. M. Hernández Díaz (Coord.), Influencias francesas en la educación española o Iberoamericana (1808-2008) (pp. 93-110). Salamanca: Globalia E. Anthema.

Hernández Huerta, J. L. (2017). Influence and reception of Freinet in Spain. Map of the historiographical maze: possible means of escape (1979-2016). História i Educació, (29), 221-246. DOI: https://dx.doi.org/10.2436/20.3009.01.190

Houssaye, J. (1997). Freinet, la pédagogie et la politique. En A. Lamihi (dir.), Freinet et l'École Moderne. Vauchrétien: Ivan Dary.

Imbernon, F. (1996). Freinet, moitos anos despois. Revista Galega de Educación, (26), 29-30.

Imbernon, F. (1996). ¿Las ideas y la práctica freinetiana están moribundas? Algunas reflexiones sobre su aportación a la escuela de hoy. Kikiriki. Cooperación educativa, (40), 4-7.

Imbernon, F. (2010). Les invariants pedagogiques i la pedagogía Freinet cinquanta anys després. Barcelona: Graó.

Jacomino, B. e Rouvière, Y. (2014). Comprendre Freinet. París: Max Milo.

Jardine, M. (1989). Pensée naturelle et méthode naturelle. En P. Clanché e J. Testanière (Dirs.), Actualité de la Pédagogie Freinet. Bourdeaux: Presses Universitaires de Bourdeaux. 
Jiménez Mier y Terán (2007). Batec. Historia de vida de un grupo de maestros. Lleida: Universitat de Lleida.

Jiménez-Mier Teran (1996). F. Freinet en España. La revista Colaboración. Barcelona: EUB.

Laboratoire de recherche coopérative de 1'ICEM (2018). Dictionnaire de la Pédagogie Freinet: Paris: ESF.

Le Gal, J. (2013). Le maître qui apprenait aux enfants à grandir. Un parcours en pédagogie Freinet vers l'autogestion. Nantes: Les Editions libertaires.

Legrand, L. (1980). Freinet hoy. Perspectivas (UNESCO), nº 3.

Meirieu, Ph. (2015). Freinet et les sciences de l'éducation: une rencontre impossible et essentielle. En N. Giauque e Ch. Tièche Christinat (Dirs), La Pédagogie Freinet. Concepts, valeurs, pratiques de clase. Lyon: Chronique Sociale.

Monceau, G. (1997). La méthode de lecture: apports sociopédagogiques. En A. Lamihi (dir.), Freinet et l'École Moderne. Vauchrétien: Ivan Dary.

Mora Teruel, F. (2013). Neuroeducación. Madrid: Alianza.

Nelson, E. (1905). Desde Norte América: Correspondencia escolar internacional. El Monitor de la Educación Común (Argentina).

Ohayon, A., Otawi, D. e Saboye, A. (eds.) (2004). L'Éducation Nouvelle, histoire, presence et devenir. Berne: Peter Lang. DOI: https://doi.org/10.3726/978-3-0352-0159-8

Pain, J. (1997). La pédagogie Freinet et la formation des maîtres. En A. Lamihi (dir.), Freinet et l'École Moderne. Vauchrétien: Ivan Dary.

Pelletier, D. (1997). Freinet, Bugnon et Profit. En A. Lamihi (dir.), Freinet et l'École Moderne. Vauchrétien: Ivan Dary.

Pettini, A. (1977). Célestin Freinet y sus técnicas. Salamanca: Sígueme.

Peyronie, H. (2006). Célestin Freinet, Pedagogía y emancipación, México: Siglo XXI.

Peyronie, H. (2015). La pédagogie Freinet: une pédagogie imagine par un fondateur charismatique, mais retravaillée - depuis plusieurs générations- par une sorte d'intellectuel collectif? En N. Giauque e Ch. Christianat (Dirs.) (2015), La Pédagogie Freinet. Concepts, valeurs, pratiques de clase. Lyon: Chronique Sociale.

Politzer, G. (1969). Crítica de los fundamentos de la psicología. Barcelona: Martínez Roca.

Porto Ucha, A. S. e Vázquez, R. (2017). La escuela activa y el entorno. Una aproximación a través de los paseos, visitas y excursiones durante la II ${ }^{a}$ República. Santiago: Andavira.

Ramos, A. (2015). Mestres de l'imprenta. El moviment Freinet al País Valencià (1931-1939). Castelló: Fundació Soler i Godes/Universitat Jaume I.

Reuter, Y.(2008). Une école Freinet. Fonctionnements et effets d'une pédagogie alternative en milieu populaire. París: L' Harmattan.

Riondet, X., Hofstetter, R. e Go, H-L. (dirs.) (2018). Les acteurs de l'Éducation Nouvelle au XXe. Siècle. Itinéraires et connexion. Grenoble: Presses Universitaires.

Saint-Fuscien, E. (2017). Freinet, pédagogue en guerres. 1914-1945. París: Perrín.

Sampedro Garrido, A. Ma . (1999). A pedagoxía Freinet en España nos tempos da II República. Sarmiento. Anuario Galego de Historia da Educación, (3), 133-156.

Seclet-Rioux, F. (1966). Freinet et l'École Moderne. Faut-il un pédagogue de progrès? L'Humanité, de 19-X. 
Schmidt, J. R. (1973). El maestro-compañero y la pedagogía libertaria. Barcelona: Fontanella. Solis, J. (2014). Le Pioulier ou mes années Freinet. Mayenne: Les Amis de Freinet.

Testaniere, J. (1989). Le PCF et la pédagogie Freinet (1950-1954). En P. Clanché e J. Testanière (dirs.), Actualité de la Pédagogie Freinet. Bourdeaux: Presses Universitaires de Bourdeaux. Vásquez, A. e Oury, F. (1967). Vers une pédagogie institutionnelle. Paris: Masperò.

Vial, J. (1989). Quelques réflexions sur la pensé active de Célestin Freinet. En P. Clanché e J. Testanière (dirs.), Actualité de la Pédagogie Freinet. Bourdeaux: Presses Universitaires de Bourdeaux.

Vergnioux, A. (1998). La notion de 1'expérience dans la Pédagogie Freinet. En H. Peyronie, Freinet, 70 ans après. Caen: Université de Caen.

Viaud, M. L. (2008). Montessori, Freinet, Steiner...une école différente pour mon enfant? Le guide pour les parents. París: Nathan.

Zurriaga, F. (1971). La pedagogía liberadora de Freinet. Un maestro de escuela. Triunfo, Extraordinario, "El niño, ese desconocido", 20-VI, 21-25. 


\section{ANEXO 1}

Para ilustración do lectorado máis novo deste texto construímos a presente síntese informativa e explicativa. O linóleo, os limógrafos e as multicopistas de tinta e de alcohol foron soportes utilizados para a escrita e para o debuxo. O linóleo é un material dúctil e económico, fabricado a partir de aceite de linaza solidificado mesturado con fariña de madeira sobre un soporte de lona ou tea basta sobre o que se poden facer incisións de debuxo mediante o uso de gubias metálicas; o uso dun rodo de caucho para entintar a superficie, sobre a que se poden ir prensando papeis, permite a obtención de copias que mostran o debuxo feito coas gubias. O limógrafo é un instrumento de reprodución de copias, composto por unha base e un bastidor de madeira ao que se lle adhería unha tea de veludo para o filtrado e tamizado da tinta de imprenta que se estendía por medio dun rodo. Pola cara interior do veludo suxeitábase o cliché que previamente fora escrito con máquina de escribir ou cun punzón; na base colocábanse as follas de papel para recibir a impresión. Era un recurso económico ante a ausencia de multicopistas mecánicas ou ciclostil, que por diversos procedementos permitían reproducir en numerosas copias de papel, textos impresos, mecanografados ou manuscritos. Os libros de vida e os xornais escolares creados nas aulas adheridas ao uso das técnicas Freinet, cando non dispuxeron dunha imprenta escolar (como as recomendadas e vendidas desde a CEL) fixeron gran utilización do limógrafo e das multicopistas entre os anos vinte e os setenta do século XX. Utilizouse igualmente outro método de reprodución de documentos por transferencia de tinta a través dunha solución base de alcohol. Esta técnica de duplicación mediante o alcohol inspirouse no hectógrafo, ou prancha de xelatina, un procedemento mediante o que un área de xelatina sirve de soporte adherente para a tinta dun clixé, permitindo de seguido a realización de copias en papel a través do prensado de follas sobre esa área. Este procedemento hectográfico foi usado en escolas rurais en Galicia nos pasados anos setenta e primeiros oitenta, xunto cos limógrados e o linoleum para a obtención de copias tanto de textos libres como de xornais escolares. Logo, comezaron a ser substituídos polas máquinas fotocopiadoras e actualmente pola comunicación dixital e os ordenadores. 